\title{
Ion Exchange Membranes for Electrodialysis: A Comprehensive Review of Recent Advances
}

\author{
Chenxiao Jiang", Md. Masem Hossain\#, Yan Li, Yaoming Wang and Tongwen Xu* \\ CAS Key Laboratory of Soft Matter Chemistry, Lab of Functional Membranes, School of Chemistry and \\ Material Science, University of Science and Technology of China, Hefei 230026, P.R. China
}

\begin{abstract}
Electrodialysis related processes are effectively applied in desalination of sea and brackish water, waste water treatment, chemical process industry, and food and pharmaceutical industry. In this process, fundamental component is the ion exchange membrane (IEM), which allows the selective transport of ions. The evolvement of an IEM not only makes the process cleaner and energy-efficient but also recovers useful effluents that are now going to wastes. However ion-exchange membranes with better selectivity, less electrical resistance, good chemical, mechanical and thermal stability are appropriate for these processes. For the development of new IEMs, a lot of tactics have been applied in the last two decades. The intention of this paper is to briefly review synthetic aspects in the development of new ionexchange membranes and their applications for electrodialysis related processes.
\end{abstract}

Keywords: Electrodialysis, ion exchange membrane, anion exchange membrane, cation exchange membrane, bipolar membrane.

\section{INTRODUCTION}

Electrodialysis (ED) is an electro-driven separation process that is used for the highly efficient desalination of brackish water, the production of ultra-pure water, water softening and the removal of other charged impurities from water streams including waste water treatment to recover some valuable elements in chemical industry and production of many important chemicals. The efficiency of this process depends on the use of ion exchange membranes (IEMs) to remove unwanted charged particles from the feed stream. For ED process, the IEMs are expected to possess high permselectivity, less electrical resistance, and good chemical, thermal and mechanical stabilities. Although many developments in IEMs have come from researches for the chloro-alkali industry and fuel cells $[1,2]$, the development of new materials and further fundamental research for the ED process are not numerous.

In fact, ion exchange membranes based electrodialysis rapidly became an industrial process for demineralizing and concentrating electrolyte solutions with the development of stable, highly selective IEM of low electric resistance in 1950 by Juda and McRae of lonics Inc. [3] and Winger et al. at Rohm in 1953 [4]. Since then, a lot of efforts have been made by many research groups to prepare membranes with desirable

*Address correspondence to this author at the CAS Key Laboratory of Soft Matter Chemistry, Lab of Functional Membranes, School of Chemistry and Material Science, University of Science and Technology of China, Hefei 230026, P.R. China; Tel: +86-551-63601587; Fax: +86-551-63601592;

E-mail: twxu@ustc.edu.cn

"Contributed equally. properties for different applications, including ED. For example, in 1960s, first salt production from sea water was realized by Asahi Co. with monovalent ion permselective membranes [5]; in 1969, the invention of electrodialysisis reversal (EDR) realized long-term run without salt precipitation or deposition on both membranes and electrodes [6]; in 1970s, a chemically stable cation exchange membrane based on sulfonated polytetra-fluorethylene was firstly developed by Dupont as Nafion® [7]; simultaneously, a composition of cation exchange layer and an anion exchange layer into a bipolar membrane in 1976 by Chlanda et al. [8] brings many novelties in electrodialysis applications today [9].

Therefore, to awake researcher's interest in this field and also to understand the present states of ED research, this review provides a comprehensive overview of IEMs covering the fundamentals as well as the recent development of IEMs in this field, and development of novel ED processes. However, this paper is not intended as a review of the literature in these areas. Instead, it is focused on recent progress in synthesis and some new important applications of major homogeneous ion exchange membranes, hybrid ion exchange membranes, as well as bipolar membranes to illustrate the improvement in ED.

\section{PREPARATION OF ION-EXCHANGE MEMBRA- NES}

This section arranges for an overview of the progress in the development of ion exchange membranes for ED. For different applications, various kinds of IEMs have been developed. Some commercially available ion-exchange membranes, 
Table 1: Main Properties of some Commercially Available lon Exchange Membranes

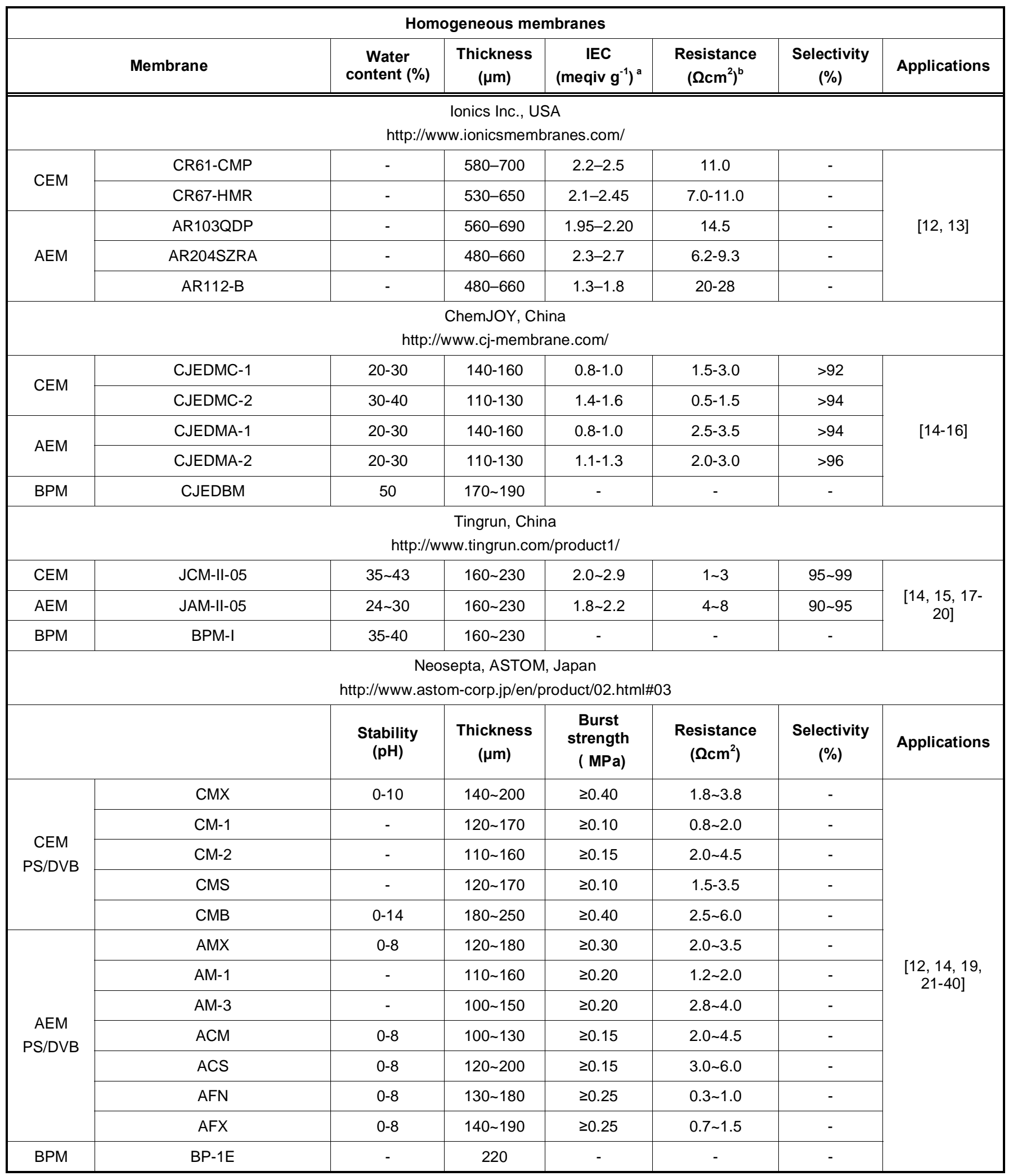


(Table 1). Continued.

\begin{tabular}{|c|c|c|c|c|c|c|c|c|c|}
\hline \multicolumn{10}{|c|}{$\begin{array}{c}\text { SELEMION }{ }^{\mathrm{TM}} \text {, AGC Engineering Co., Ltd, Japan } \\
\text { http://www.selemion.com/SELC.pdf }\end{array}$} \\
\hline \multirow{3}{*}{ CEM } & \multirow{3}{*}{\multicolumn{2}{|c|}{$\begin{array}{l}\text { General purpose } \\
\text { membranes }\end{array}$}} & CMV & - & 120 & - & 3.0 & $>96$ & \multirow{6}{*}[41-46]{} \\
\hline & & & CSO & - & 100 & - & 2.3 & $>97$ & \\
\hline & & & CMF & - & 440 & - & 2.5 & $>95$ & \\
\hline \multirow[t]{3}{*}{ AEM } & \multirow{3}{*}{\multicolumn{2}{|c|}{$\begin{array}{l}\text { Special purpose } \\
\text { membranes }\end{array}$}} & AAV & - & 120 & - & 6.0 & $>95$ & \\
\hline & & & ASV & - & 120 & - & 3.7 & $>97$ & \\
\hline & & & $\mathrm{AHO}$ & - & 300 & - & 20 & $>95$ & \\
\hline & & & & & & FuMA-Tech & $\mathrm{mbH}$, Germany & & \\
\hline \multirow{6}{*}{ CEM } & FKL & & & $1-14$ & $100 \sim 130$ & $1.0 \sim 1.2$ & $6 \sim 10$ & $98 \sim 99$ & \multirow{8}{*}{ [46-53] } \\
\hline & F-10180 & & & $1-14$ & $150 \sim 180$ & 1.0 & $<0.5$ & $>99$ & \\
\hline & CMI-7000 & Poly & bylene & $1-10$ & 450 & 1.6 & $25 \sim 30$ & $>97$ & \\
\hline & FKD & & & $1-14$ & 75 90 & $1.2 \sim 1.4$ & $1.0 \sim 1.2$ & $>94$ & \\
\hline & \multirow{2}{*}{ FKS } & & ster & $1-9$ & $75 \sim 130$ & $0.8 \sim 1.2$ & $2.0 \sim 4.5$ & $98 \sim 99$ & \\
\hline & & & & $1-14$ & $10 \sim 50$ & $1.3 \sim 1.4$ & $0.9 \sim 1.9$ & $98 \sim 99$ & \\
\hline \multirow{2}{*}{ AEM } & \multirow{2}{*}{ FAS } & & & $1-14$ & $10 \sim 50$ & $1.6 \sim 1.8$ & $0.4 \sim 0.8$ & $94 \sim 97$ & \\
\hline & & & ster & $1-9$ & $75 \sim 130$ & $1.0 \sim 1.4$ & $2.0 \sim 3.0$ & $92 \sim 97$ & \\
\hline \multicolumn{10}{|c|}{ Heterogeneous membranes } \\
\hline \multicolumn{10}{|c|}{$\begin{array}{c}\text { Qianqiu, China } \\
\text { http://www.china-qianqiu.com/ }\end{array}$} \\
\hline \multicolumn{4}{|c|}{ Membrane } & $\begin{array}{c}\text { Water } \\
\text { content }(\%)\end{array}$ & $\begin{array}{l}\text { Thickness } \\
\qquad(\mu \mathrm{m})\end{array}$ & $\begin{array}{c}\text { IEC } \\
\left(\text { meqiv }^{-1}\right)\end{array}$ & $\begin{array}{l}\text { Resistance } \\
\qquad\left(\Omega \mathrm{cm}^{2}\right)\end{array}$ & $\begin{array}{l}\text { Selectivity } \\
\qquad(\%)\end{array}$ & Applications \\
\hline CEM & \multicolumn{3}{|c|}{ Qian-qiu CEM } & - & $460 \sim 500$ & 2.0 & 13 & 93 & \multirow{2}{*}[54]{} \\
\hline AEM & \multicolumn{3}{|c|}{ Qian-qiu AEM } & - & $460 \sim 500$ & 1.8 & 16 & 95 & \\
\hline \multicolumn{10}{|c|}{$\begin{array}{c}\text { Shchekinoazot, Russia[55] } \\
\text { http://n-azot.ru/download/product/product } 348\end{array}$} \\
\hline \multicolumn{4}{|c|}{ Membrane } & $\begin{array}{l}\text { Contact } \\
\text { angle }\left({ }^{\circ}\right)\end{array}$ & $\begin{array}{l}\text { Thickness } \\
\qquad(\mu \mathrm{m})\end{array}$ & $\begin{array}{c}\text { IEC } \\
\left(\text { meqiv } \mathbf{g}^{-1}\right)\end{array}$ & $\begin{array}{l}\text { Conductivity } \\
\left(\mathrm{mS} \mathrm{cm}^{-1}\right)\end{array}$ & $\begin{array}{l}\text { Selectivity } \\
\text { (\%) }\end{array}$ & Applications \\
\hline \multirow{2}{*}{ CEM } & & $\mathrm{K}-40$ & & $52 \sim 58$ & $470 \sim 490$ & $1.6 \sim 1.8$ & $7.4 \sim 7.7$ & - & \multirow{4}{*}[56,57]{} \\
\hline & & $-40 / N$ & & $61 \sim 67$ & $490 \sim 510$ & $1.6 \sim 1.8$ & $8.0 \sim 8.6$ & - & \\
\hline \multirow{2}{*}{ AEM } & & $A-40$ & & $48 \sim 52$ & $450 \sim 490$ & $3.12 \sim 3.28$ & $7.2 \sim 7.8$ & - & \\
\hline & & $-40 M$ & & $45 \sim 49$ & $450 \sim 490$ & $3.12 \sim 3.28$ & $5.2 \sim 5.8$ & - & \\
\hline
\end{tabular}

a Ion exchange capacity was determined for wet membranes in the sodium form (cation exchange membranes) or in the chloride form (anion exchange membranes); ${ }^{\mathrm{b}}$ The measurement conditions to determine the resistance (area resistance) varied with companies: AGC Engineering Co., Ltd,0.5M NaCl at $25{ }^{\circ} \mathrm{C}$; FuMA-Tech, $\mathrm{GmbH}, 0.6 \mathrm{M} \mathrm{NaCl}$ at $25^{\circ} \mathrm{C}$; Astom Co., $0.5 \mathrm{~N} \mathrm{NaCl}$ at $25^{\circ} \mathrm{C}$; Tianwei Co., $0.1 \mathrm{~N} \mathrm{NaCl}$ at $17{ }^{\circ} \mathrm{C}$. 
manufacturers and their properties are shown in Table $1[10,11]$.

\subsection{Homogeneous Ion Exchange Membrane}

In order to supply suitable membranes for ED application and to expand the opportunity to new potential applications, the search for new materials for ion-exchange membranes has kept on the rise. To prepare homogeneous IEMs, various tactics are available to introduce ionic groups. These tactics can be divided into three classes based on the starting materials.

1) Polymerization or polycondensation of monomers; at least one of them must comprise a moiety that either is or can be made cationic or anionic groups, respectively. Then the charged polymers undergo film processing to form membranes

2) Charge moieties insert ion to polymer chains followed by the formation of membranes

3) Introduction of functional charge groups on the already film-formed membranes either directly by grafting of a functional monomer or indirectly by grafting nonfunctional monomer followed by functionalization reactions.

\subsubsection{Direct Polymerization from Monomer Units}

The direct synthesis of polymer from monomer units gives excellent opportunity to control the functional groups quantity and distribution along the polymer backbones. Moreover, this process helps to regulate both microstructure and properties of the ion-exchange membranes. IEMs via direct polymerization of monomers, in which, at least one of them must contain a moiety that is or can be made anionic or cationic, respectively, have been successfully reported [58-60].

If such amembrane is prepared from monomer, styrene and divinyl benzene are most frequently used starting material for a conventional hydrocarbon type ion exchange membrane for industrial uses, from which cation exchange membranes (CEMs) are readily obtained through sulfonation of the aromatic ring with chlorosulfonic acid whereas anion exchange membranes (AEMs) are prepared through halomethylation, especially chloromethylation, followed by quaternization. Usually chloromethyl ether (CME), a carcinogenic and hazardous chemical, was used for chloro- methylation reaction and its use has been restricted since 1970s.

As shown in Figure 1, alternative methods have been proposed to minimize the hazards involved in the preparation of AEMs such as polymerization of halomethyl substituted aromatic monomers (i.e. chloromethylstyrene), followed by quaternization with alkylamine [58], and polymerization of p-methylstyrene and subjected to benzylic bromination followed by amination to obtain quaternary ammonium sites [59].

As electronic properties of conducting polymers (CP) are useful for ED application, they are materials

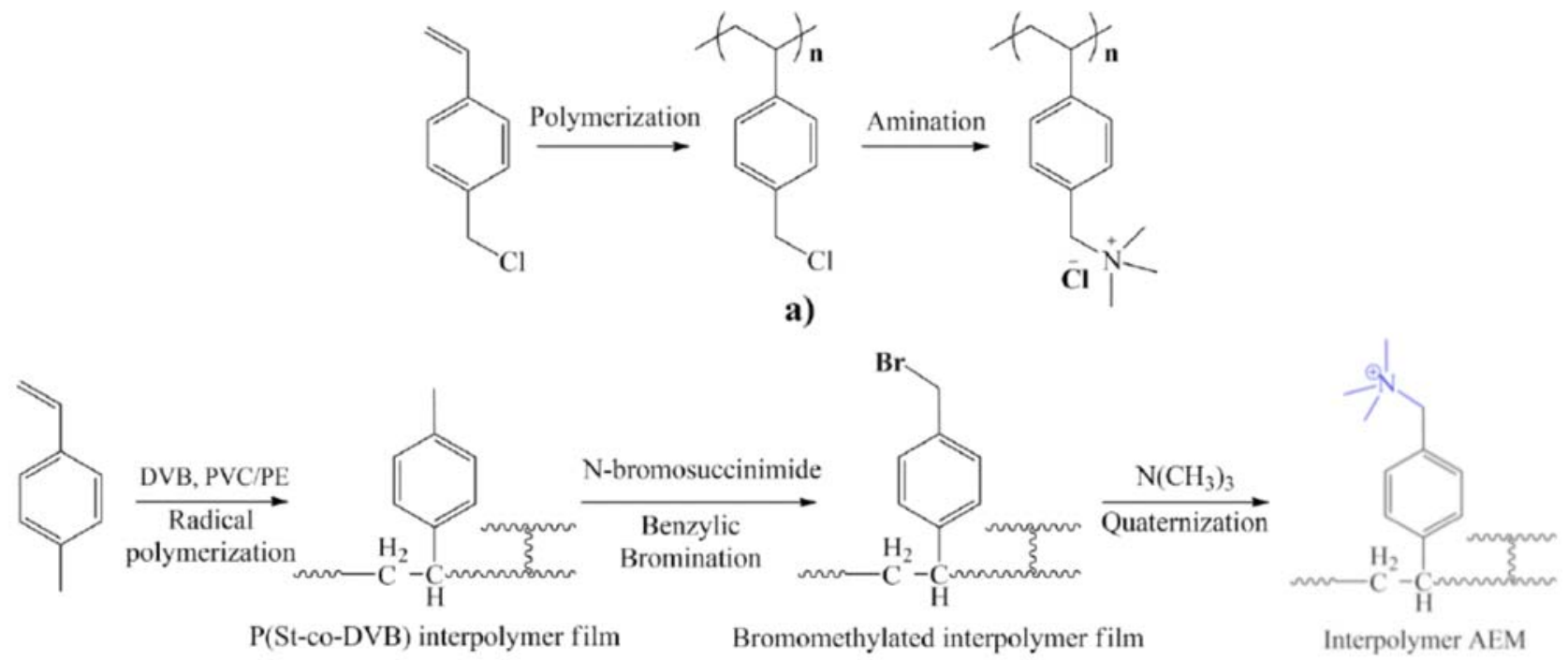

b)

Figure 1: Safer route for preparing anion exchange membrane a) from chloromethylstyrene and b) from p-methylstyrene [59]. Copyright (2014), Modified with permission from Elsevier. 
with an enormous projection. Among them, polythiophene derivatives are very important, since their serious problems of solubility and processability have been solved recently. Poly(2-thiophen-3-ylmalonic acid), a new CP bearing two carboxylate units per thiophene ring, has been derived from the alkaline hydrolysis of the poly(2-thiophene-3-yl-malonic acid dimethyl ester), which was obtained by chemical oxidative coupling polymerization [60].

\subsubsection{Direct Modification of Polymer Backbone}

For soluble polymers, polyarylene polymers containing aromatic pendant groups on polymer backbones such as poly aryl sulfone, poly aryl ketone, and polyphenylene oxides, the corresponding membranes can be obtained either by introducing anionic or cationic moieties, followed by the dissolving of polymer and casting it into a film [61-74]. For the preparation of IEMs, these polymers are attractive as the polymer matrix due to several reasons: (1) their high mechanical and thermal stability, (2) good processibility, (3) relatively high glass transition temperature ( $\mathrm{Tg}$ ), (4) low cost, and (5) the ability to chemically modify the polymer backbone via the electrophilic substitution at their aromatic skeletons [11]. However, for membrane preparation with these soluble polymers, its chemical stability is not so good and often needs post treatment, such as crosslinking $[65,66]$.

Poly(aryl sulfone)

Poly(arylsulfone)s such as polyether sulfones (PES), have strong mechanical, thermal and chemical stability and have been successfully used as ion exchange membranes in electro-chemical applications [61-66]. For use as a cation exchange membrane, PES must be functionalized to incorporate fixed negatively charged groups. For the functionalization of PES, sulfonation is commonly used over other forms such as carboxylation or phosphonation, as the process is comparatively simple and yields membranes show good ion transport properties. There are different sulfonation methods to add sulfonic acid groups to PES chain in heterogeneous or homogeneous media with sulfuric or chlorosulfonic acid. However, if chlorosulfonic acid is used as sulfonating agent, sometimes PES chains cleave or undergo branching and crosslinking reactions by the conversion of the intermediate sulfonic acid group into a partially branched or cross-linked sulfone unit [75]. Additionally, the amount of these side reactions for the sulfonation of PES mostly depends on the reaction conditions and polarity of the solvents used [61].
Also, it is difficult to control the degree of sulfonation and chemical structure of a sulfonated polymer if the polymer is directly sulfonated with chlorosulfonic acid or concentrated sulfuric acid. In the course of the sulfonation process, it is often the main chain that becomes sulfonated, however side chain sulfonation increase the chemical and mechanical properties of the polymer [76]. Hence, for potential application in ED with suitable properties, random and multiblock side-chain sulfonated polyether sulfones (SPES) was prepared by condensation polymerization using 2,5-diphenylhydroquinone, 4,4'-Difluorodiphenyl sulfone, and 4,4'dihydroxydiphenyl sulfone as monomer [62].

Noted that electrochemical properties of SPES membranes not only depend on the sulfonation processes and structure of the PES but also on the way of preparation $[63,64]$. Membrane prepared by the solvent evaporation method shows better electrochemical properties than the membrane prepared by the phase inversion method. Also, by tuning both the wet film thickness and film drying time before immersing in water bath to form membrane sheet, the morphology of the membranes can be easily controlled [64].

\section{Poly(aryl ether ketone)}

Poly (aryl ether ketone) has also been used as IEM matrix [67-70]. The modification of the polymer backbone can be carried out in the similar way used for PES polymer material. However, uncrosslinked sulfonated membranes show high swelling ratio which reduces mechanical properties and ion permselectivity, and thus prohibits them from applying in electromembrane processes, especially at higher temperature. For these reasons, these polymers are often blended with non-functional polymers or crosslinked by different means to enhance and modify the transport properties $[69,70]$.

\section{Polyphenylene Oxides (PPO)}

From engineering polymer poly(2,6-dimethyl-1,4phenylene oxide) (PPO), anion exchange membranes have been prepared either by chloroacetylationquaternary amination or by bromination-amination process as shown in Figure 2 [71-73].

The new route for preparing AEMs as proposed in the Figure $\mathbf{2 a}$ shows several advantages over the traditional one (chloromethylation, followed by quaternization): (1) avoiding the use of chloromethyl methyl ether (CME), a carcinogen and is potentially 


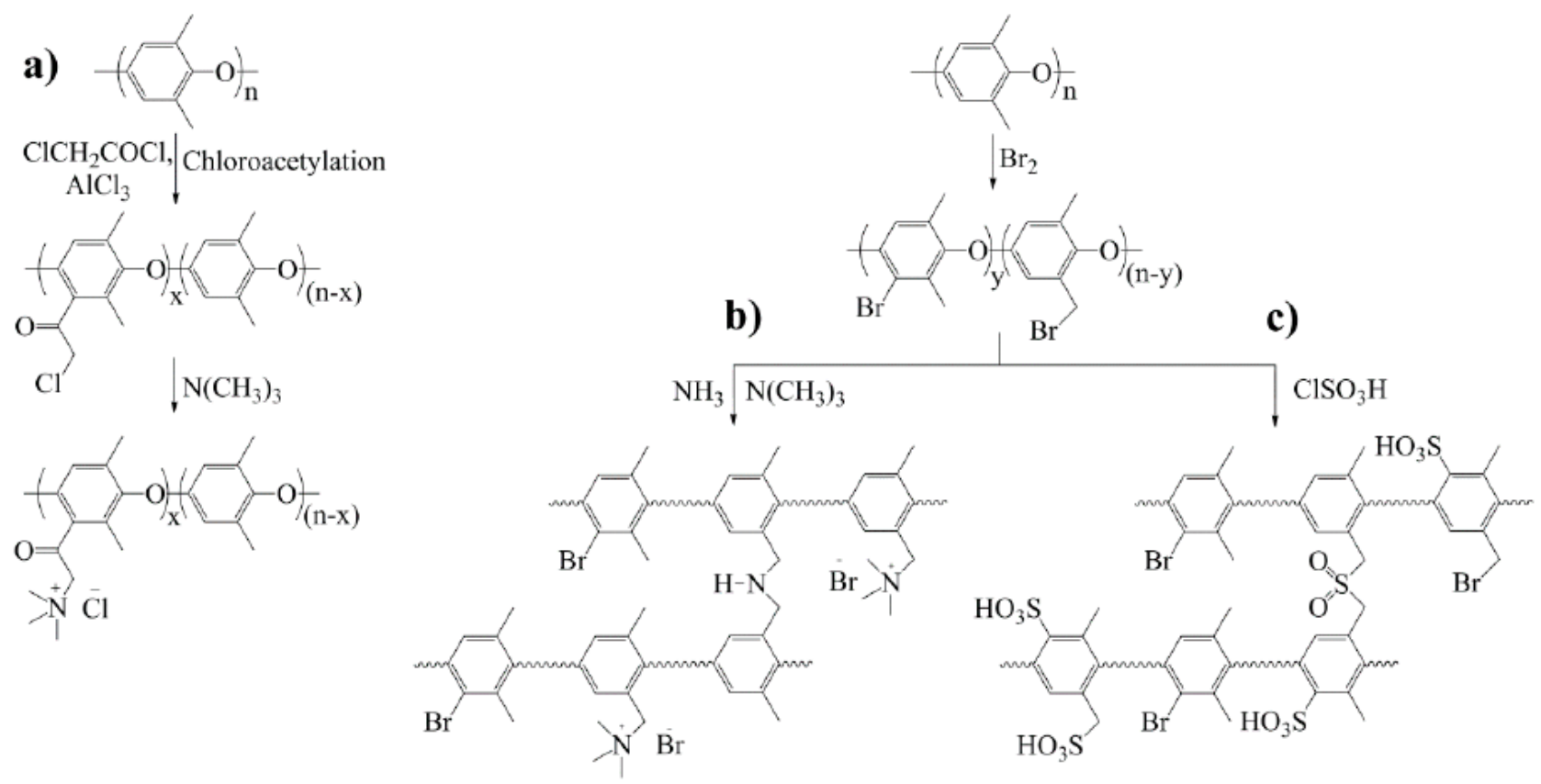

Figure 2: Main reactions and structures of IEMs from PPO: (a) anion-exchange membranes prepared by Friedel-Crafts chloroacetylation, (b) anion-exchange membrane prepared by bromination and amination and (c) cation-exchange membrane prepared by bromination and sulfonation reaction [10, 71]. Modified with permission from Elsevier.

harmful to human health, normally used in the conventional preparation procedure of AEMs, and the process can be easily controlled through the FriedelCrafts reaction, which is a kind of simple and well investigated reactions; (2) the used materials are conventional agents with low toxicity [71]. Via chloroacetylation, the membranes with high IEC can be obtained. Nevertheless, the physical stability of the resultant membranes still requires more improvement. This problem can be solved by the introduction of bromination substitutions (Figure $\mathbf{2 b}$ ) which can occur on both aryl and benzyl positions. Now it can be easily aminated and can also be created cross-linking to some extend among the functional groups of the membranes [72, 73]. It is noted that this crosslinking can also be conducted after the formation of base membrane [10].

The cation exchange membrane can also be obtained with the same way: by bromination and sulfonation (Figure 2c) or directly by sulfonation [10, 74].

\subsubsection{Charge Induced on the Film Membranes}

The IEM can also be prepared by forming the noniongenic polymer films firstly, subsequently by the introduction of charged functional groups onto the formed polymer films either directly by grafting of a functional monomer or indirectly by grafting nonfunctional monomer followed by functionalization reaction.

Both porous and non-porous membranes can be used as the film substrates. Typical examples of grafting substrates include hydrocarbon polymer based films of polyethylene (PE), polypropylene (PP), polyalkene (polyalkene non-woven fabrics (PNF)), and fluorocarbon polymer based films of polyvinylidene fluoride (PVDF) and polytetrafluoroethylene (PTFE).

For the grafting agents, there are two major categories; (1) functional monomers such as acrylic acid, methacrylic acid that can be directly attached to the substrate as charged functional groups and (2) non-functional monomers such as styrene, glycidyl methacrylate (GMA, the ester of methacrylic acid and 2,3-epoxy-propanol that bears a reactive epoxy group) and vinylbenzyl chloride that can be further chemically modified into the ion-exchangeable.

Radiation-induced graft copolymerization is well known for its merits and potential to transform the chemical and the physical properties of pre-existing polymeric materials without altering their intrinsic properties. Using this methodcation exchange membrane for electrodialysis application was early prepared by grafting of methacrylic acid onto preformed polymer film PE [77]. Another type of membranes prepared by grafting of fluorinated monomers such as 
methyl trifluoro-proproenoate onto PTFE films was found to be promising for electrodialysis processes as the use of fluorinated monomer imparted more chemical stability to membranes [78].

Both anion and cation exchange membranes can be obtained from the same precursor prepared by the radiation-induced grafting of glycidyl methacrylate (GMA), and subsequent chemical modification of poly(GMA) graft chains by different ways i.e. amination gives anion exchange, sulfonatin or phophonation gives cation exchange membranes [79, 80]. The anion exchange membranes can also be prepared by grafting of vinylbenzyl chloride onto fluorinated PVDF films followed by amination reaction to convert the functional groups to amine derivatives [81].

Into Nafion precursor, made by DuPont, usually charge induces through the hydrolysis of this resin with sulfuric acid and hydrogen peroxide to form a perfluorosulfonic polymer. It is a logical support for a thin carboxylic acid-form membrane onto Nafion to decrease water permeability because the sulfonic acid form of this membrane is highly permeable to water and ions. The carboxylate layer could be created by two ways; (1) cast or laminated onto a sulfonate layer (e.g., Nafion 90209) and (2) by modifying the surfaces of a sulfonate-form membrane. To create very thin, defect-free carboxylate layers on already thin starting films, surface modification is the better way [82]. The general surface modification reaction of Nafion has included four primary steps: reduction of sulfonyl fluoride to sulfinic acid, hydrolysis of residual sulfonyl fluoride to sulfonate, oxidation of sulfinic acid to carboxylic acid, and cleaning of the resultant ionomer.

\subsection{Mixed Matrix lon-Exchange Membrane}

Actually it is difficult to acquire all the targeted properties in one IEM to satisfy the requirements of particular application. In fact, different applications usually require specific membrane properties. For electrodialysis, the ion-exchange membranes are expected to possess high permselectivity, excellent conductivity, and good chemical, thermal and mechanical stabilities. As most polymer based IEMs have some common drawbacks including insufficient mechanical, chemical and thermal stabilities, and poor fouling resistance, they are still insufficient for the ED process. The concept of combining two distinct materials forming a new composite that keeps desirable properties of both components is an alternative method for the development of new IEMs with excellent electrochemical properties and good mechanical stability. Table 2 provides examples of composite (or mixed matrix) ion-exchange membranes prepared from different routes and some of their properties for electrodialysis applications.

Inorganic-organic composite materials have gained increasing attention due to its specific properties

Table 2: Preparation Routes of Mixed Matrix lon-Exchange Membranes and the Resultant Membrane Properties

\begin{tabular}{|c|c|c|c|}
\hline $\begin{array}{l}\text { Mixed matrix } \\
\text { system }\end{array}$ & $\begin{array}{l}\text { Preparation } \\
\text { route }\end{array}$ & Property & Reference \\
\hline PVA-Silica & Sol-gel & $\begin{array}{l}\text {-Permselectivity of } 0.91-0.94 \\
\text {-Conductivity up to } 7.61 \mathrm{mS} \mathrm{cm}\end{array}$ & {$[83,84]$} \\
\hline $\begin{array}{l}\text { sPES-sulfonated } \\
\text { silica }\end{array}$ & Blending & $\begin{array}{l}\text { The composite showed good ionic conductivity, transport properties while } \\
\text { maintain acceptable mechanical and thermal stability. }\end{array}$ & [85-88] \\
\hline PVDF-Silica & Blending & $\begin{array}{l}\text {-IEC of } 0.8-2.0 \\
\text {-Porosity of } 0.10-0.19 \\
\text {-Permselectivity up to } 0.98\end{array}$ & [89-91] \\
\hline PVC-Rasine & Blending & $\begin{array}{l}\text {-IEC of } 1.1-4.0 \\
\text {-Transport number up to } 0.96 \\
\text {-Permselectivity up to } 0.91\end{array}$ & [92-95] \\
\hline $\begin{array}{l}\text { PVC-SBR- } \\
\text { Rasine }\end{array}$ & Blending & $\begin{array}{l}\text {-Membrane resistance of } 4.4-13.0 \Omega . \mathrm{cm}^{2} \\
\text {-Transport number up to } 0.99 \\
\text {-Permselectivity of } 0.67-0.99\end{array}$ & [96-101] \\
\hline PES-Rasine & Blending & $\begin{array}{l}\text { Membrane prepared by solvent evaporation method showed higher transport } \\
\text { number, }\end{array}$ & [102] \\
\hline HIPS-PAni & Blending & $\begin{array}{c}\text { The ion percent extraction for mixed matrix membrane is similar to that } \\
\text { observed for the commercial membrane. }\end{array}$ & [103-105] \\
\hline
\end{tabular}


originated from the components in the composite. The organic counterpart of the composite membrane provides opportunities of chemical modifications, structure flexibility, and processibility on large scale. On the other hand, the main characters of the inorganic fillers in composite membranes are to retain water inside the membrane, to improve conductivity, while maintaining good chemical, mechanical and thermal stability.

Mixed matrix ion-exchange membrane can be made by several routes including sol-gel process, intercalation, blending, in situ polymerization, molecular self-assembling, but probably physical blending and sol-gel process are the most prominent technique as depicted in Figure 3 [11]. For the first approach, the resultant membranes normally show phase separation from aggregated fillers, causing mechanical instability of the composite membranes. On the other hand, solgel method offers better interconnection between two domains.

It is known that a big problem in development of composite materials is the distribution of inorganic nanoparticles in the organic matrix due to the aggregate tendency of the nanoparticles. However, by enhancing the interaction among them via covalent bond, hydrogen bond, and electrostatic interaction, this problem can be reduced. Frequently used strategies for enlightening the interaction between inorganic and organic matrix are; (1) functionalization of inorganic fillers or/and polymer matrix (2) introduction of the inorganic filler on the polymer chains. The functionalization of mesoporous $\mathrm{SiO}_{2}$ using sulfonate groups is a good policy to enhance the distribution of the nanoparticles in the polymer matrix [85-88]. Moreover, the addition of functionalized mesoporous nanoparticles not only increases charged functional groups in the composites, but also improves the ionic transport properties due to their high surface area and well-accessible mesopores.

Mixed matrix ion-exchange membrane can also be made by mechanical incorporation of powered ionexchange resin into sheets of rubber, PVC, acrylonitrile copolymers or some other extrudable or mouldable matrix. Such membranes can be prepared by different methods; (1) dry moulding of inert film forming polymers and ion-exchange particles and then milling the mould stock, (2) calendaring ion-exchange particles into an inert plastic film, and (3) resin particles can be dispersed in a solution containing a film forming binder and then the solvent is evaporated to give ionexchange membrane. To increase mechanical stability, such composite membranes may also be reinforced with a chemically resistance fabric.

Recently, a two-step phase inversion membrane formation technique has been developed for the preparation of composite membrane which allows a good control of the membrane structure, porosity and electrochemical properties [86]. In this procedure polymer with ion exchange group firstly dissolved in a solvent. The polymer solution is then cast on glass
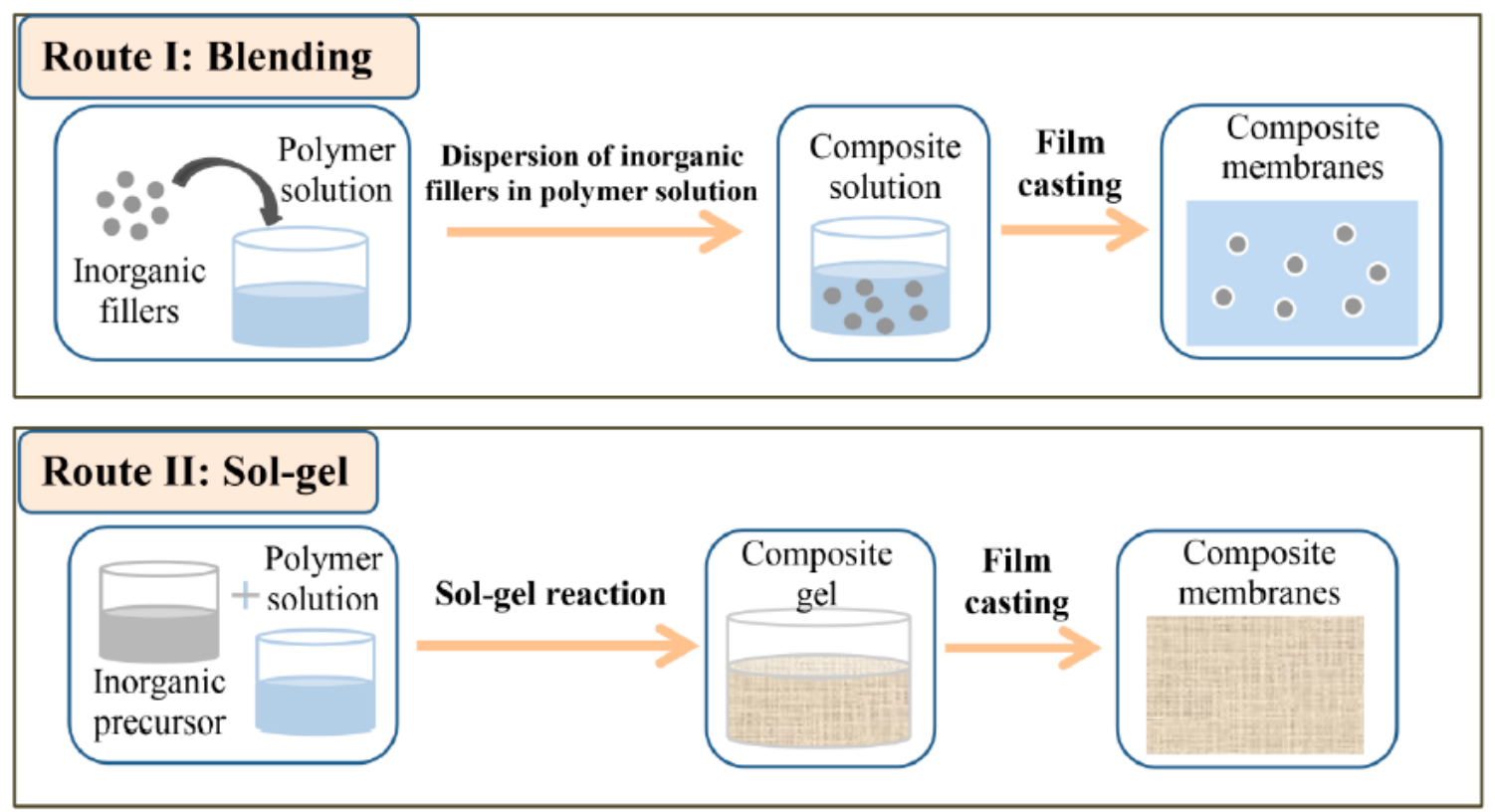

Figure 3: Two frequently used preparation methods for mixed matrix ion-exchange membranes (composite membranes): route I blending and route II sol-gel method [11]. Copyright (2013), modified with permission from John Wiley \& Sons, Inc. 
substrates with different solution thickness and then partially dried in a vacuum oven at $60^{\circ} \mathrm{C}$ with different aging times before precipitating in $60-70^{\circ} \mathrm{C}$ DI water. By tuning the aging time before precipitating the partly dried film in water bath, membrane porosities can be control via this new technique. Among the IEMs prepared by this method, membranes with interconnecting pore structure show good ionic conductivity but their transport number and selectivity are very poor. On the other hand, membranes with smaller pores and denser surface are more selective, but less conductive.

\subsection{Bipolarmembrane}

A bipolar membrane (BPM) is a composite membrane consists of an anion-exchange layer and a cation-exchange layer and usually has a catalytic intermediate layer ( $I n L)$ between the two ion exchange layers. Recently bipolar membrane has gained increasing attention as an efficient tool for the production of acids and bases from their corresponding salts by electrically enforced accelerated water dissociation. Actually, water dissociation takes place at the $\operatorname{lnL}$ between ion exchange layers (CEL and $A E L$ ) of BPM and particularly depends on their properties.

However, a noble BPM should have high selectivity, water dissociation efficiency, acid and base stability over wide $\mathrm{pH}$ range, low salt diffusion, along with good thermal and mechanical stability. These desired properties can be obtained by suitable membrane forming materials, selection of $\mathrm{InL}$ and membrane casting methodology.

For preparing bipolar membranes with suitable properties, various methods has been initiated, such as laminating polymeric films with fixed charges of opposite polarity with heat and pressure or with an adhesive paste [106], preparing by casting a cation exchange polyelectrolyte solution onto an anion exchange membrane or vice-versa [107], or preparing from the same base membrane by simultaneous functionalizing at the two membrane sides [108] or selectively functionalizing on one side to give cation selectivity and on the other side to give anion selectivity [109], etc. Among these, the casting method is the most efficient one for the preparation of such membrane because it is simple, less costly and also allows a bipolar membrane with desired properties [110]. Using this method, novel bipolar membranes have been prepared by casting the sulfonated PPO solution on a series anion exchange membranes [111].
Actually, the function of the two ion exchange layers in a bipolar membrane is to selectively transport the water dissociation products, protons and hydroxyl ions, at the $\operatorname{InL}$ and block co-ions. However, water dissociation mainly depends on the charged groups and structure of $\mathrm{InL}$ region and thus usually is modified to enhance the bipolar membrane's performance. As catalysts in the bipolar junction, immobile weak acids or bases with an equilibrium constant of the acid/base pair close to that of the water dissociation reaction $(\mathrm{pKa}=$ 7) could be used, such as amino groups, sulfonic acid groups, amide groups, hydroxyl groups, pyridine groups [112-116] as well as metal ion/metal ion complexes, such as Aluminum, Magnesium, Iron, Cupper, etc. [116-120]. Also, metal ions are immobilized by placing their insoluble salts or low soluble (multivalent metal ion) hydroxides in the intermediate layer or using a soluble salt with a subsequent treatment [121].

Our research group has developed a series of bipolar membranes to demonstrate the catalytic activity of different macromolecules whose anion exchange layers were modified with a variety of (bio)macromolecules beforehand. The list includes hydrophilic materials such as hyperbranched aliphatic polyesters of the Boltorn series, polyethylene glycol (PEG), polyvinyl alcohol (PVA), polyamphoteric bovine serum albumin (BSA), and a dendrimer molecule polyamidoamine (PAMAM) which possesses higher amino groups [113, 122-125]. The catalysts can be immobilized before or after the film formation. There have been several techniques applied: spray or dipcoating, incorporating in the polymer material by even dispersion, by electrochemical methods after formation of the layers or by in situ polymerization, electrospray deposition, layer-by-layer (LbL) assembly of polyelectrolyte multilayers [126-130].

The LbL deposition of polyelectrolyte multilayers is an effective method to introduce molecularly thin catalyst groups at this interface of bipolar membranes [130]. By this method, the bipolar membranes are prepared by first modifying an AEM via successive dipping LbL assembly, then casting a thin highly charged intermediate layer followed by casting a CEM.

\section{ELECTRODIALYSIS APPLICATIONS OF ION EXCHANGE MEMBRANES}

Electrodialysis (ED) as a novel process has grown rapidly during last decades. At first the ED was mainly used for the separation and production processes 
based on ion exchange membranes, which mainly includes conventional electrodialysis (CED), electroelectrodialysis (EED), bipolar membrane electrodialysis (BMED or EDBM) and electrodialysis deionization (EDI), etc. There are several comprehensive reviews which summarized ED utilization in organic acid productions [131], in environmental protection [132], for sustainable development [133], in separation process [134], in bioproducts transforming [135]. During last decades of development, ED has also been used for the energy reclamation from concentration gradient that called reverse electrodialysis (RED) [136-138]. However, the following will focus on the reclamation of useful resources such as nitrogen, phosphorus, precious metals and organic compounds from factory byproducts, wastewaters and brines, etc.

\subsection{Recovery of N\&P}

Nitrogen and phosphorus are very important nutrients for the grown of crops which phosphate account for $2-4 \%$ of the dry weight of most cells. During the past decades, the demand for nitrogen and phosphorus increases rapidly for growing dairy- and meat-based diets. However, phosphorus has no substitute in food production and can only be extracted from phosphorous mining; in the same case, the production of ammonia requires nearly $1 \mathrm{~m}^{3}$ of natural gas per $\mathrm{kg}$, moreover, commercial nitrogen fertilizer cost increase rapidly with increase of raw materials price. The excessively dissolved phosphorus and nitrogen nutrient would induce water deterioration and eutrophication as well as green-house gas emissions. It is important to consider any possible methods to recycle nitrogen and phosphorus from wastewater. Electrodialysis as an efficient separation process has been used for the extraction of nitrogen and phosphate. Akyeva et al. [139], used electrodialysis to treat wastewater effluent from phosphoric acid extraction process. In this process, the phosphate extraction efficiency greatly depends on the applied current density. Particularly, low value of current density is suitable to block transition of triple-charged ions $\left(\mathrm{PO}_{4}{ }^{3-}\right)$ as a consequence; conventional electrodialysis is a potential process for phosphorus reusing. Zhang et al. [48], used electrodialysis configured with selective ion exchange membrane (SED) to recover phosphate from struvite reactor (see Figure 4). The selective membrane only allows the passive of mono-valent ions and blocks the multi-valent ions. To maintain the recovery rate of phosphate, the experiments were carried out at $\mathrm{pH} 9$ which was adjusted by adding $\mathrm{NaOH}$. Here phosphate was removed from feed compartment and recovered at product compartment simultaneously. For the aerobic effluent as the phosphate source, the current efficiency initially reached $72 \%$, with a satisfying phosphate concentration $\left(9 \mathrm{mmol} \mathrm{L}^{-1}\right)$. In the experiments with the anaerobic effluent, the phosphate flux was $16 \mathrm{mmolm}^{-2}$ $\mathrm{h}^{-1}$. A cost evaluation shows that $1 \mathrm{kWh}$ electricity can produce $60 \mathrm{~g}$ of phosphate by using a full scale stack, with a desalination rate of $95 \%$ on the feed wastewater. Finally, a struvite precipitation experiment shows that $93 \%$ of phosphate can be recovered. In our group [17], both conventional electrodialysis and bipolar membrane electrodialysis as well as their integration were used to recover phosphate from excess sludge. Firstly, simulated wastewater was treated with CED to recover phosphate. The concentration of phosphate was enriched to $1600 \mathrm{mg} / \mathrm{Land}$ then was pumped into EDBM process and transformed to valuable alkali solution and phosphate acid. Using continuous operation model, $95.8 \%$ recovery ratio could be achieved. However, at $50 \mathrm{~mA} / \mathrm{cm}^{2}$ operating current density, the net production of phosphorus acid was about $0.075 \mathrm{~mol} / \mathrm{L}$ with a current efficiency about $75 \%$ and energy consumption rate about $29.3 \mathrm{kWh} /(\mathrm{kg}$ $\mathrm{H}_{3} \mathrm{PO}_{4}$ ). There also some other phosphorus recovery ED process, such as phosphoric acid from liquid crystal display (LCD) manufacturing process [33], the recovery of organic phosphorus composition from seawater [140], etc.

\subsection{Recovery of Base}

$\mathrm{NaOH}$ as its inherent strong absorption ability toward acid gas has been used to remove $\mathrm{H}_{2} \mathrm{~S}, \mathrm{CO}_{2}$, and $\mathrm{CS}_{2}$ from the gaseous petroleum fractions and corrosive streams which are usually called sweetening. Simultaneously, in prewash section of a Merox tower, acidic gases $\left(\mathrm{H}_{2} \mathrm{~S}, \mathrm{CO}_{2}\right)$ are eliminated by using caustic solution. This process can be represented by the following reactions:

$$
\begin{aligned}
& \mathrm{H}_{2} \mathrm{~S}+\mathrm{NaOH} \rightarrow \mathrm{Na}_{2} \mathrm{~S}+2 \mathrm{H}_{2} \mathrm{O} \\
& \mathrm{CO}_{2}+2 \mathrm{NaOH} \rightarrow \mathrm{Na}_{2} \mathrm{CO}_{3}+\mathrm{H}_{2} \mathrm{O}
\end{aligned}
$$

The excess amount of $\mathrm{NaOH}$ is often used to achieve complete elimination of acidic gases and hence a large amount of $\mathrm{NaOH}$ is periodically discarded via spent caustic stream which would induce great environmental pollution. Keramati et al. [141], used electrodialysis to recover $\mathrm{NaOH}$ from waste stream of Merox tower (see Figure 5). Moreover, to improve $\mathrm{NaOH}$ recovery ratio and the applied current 


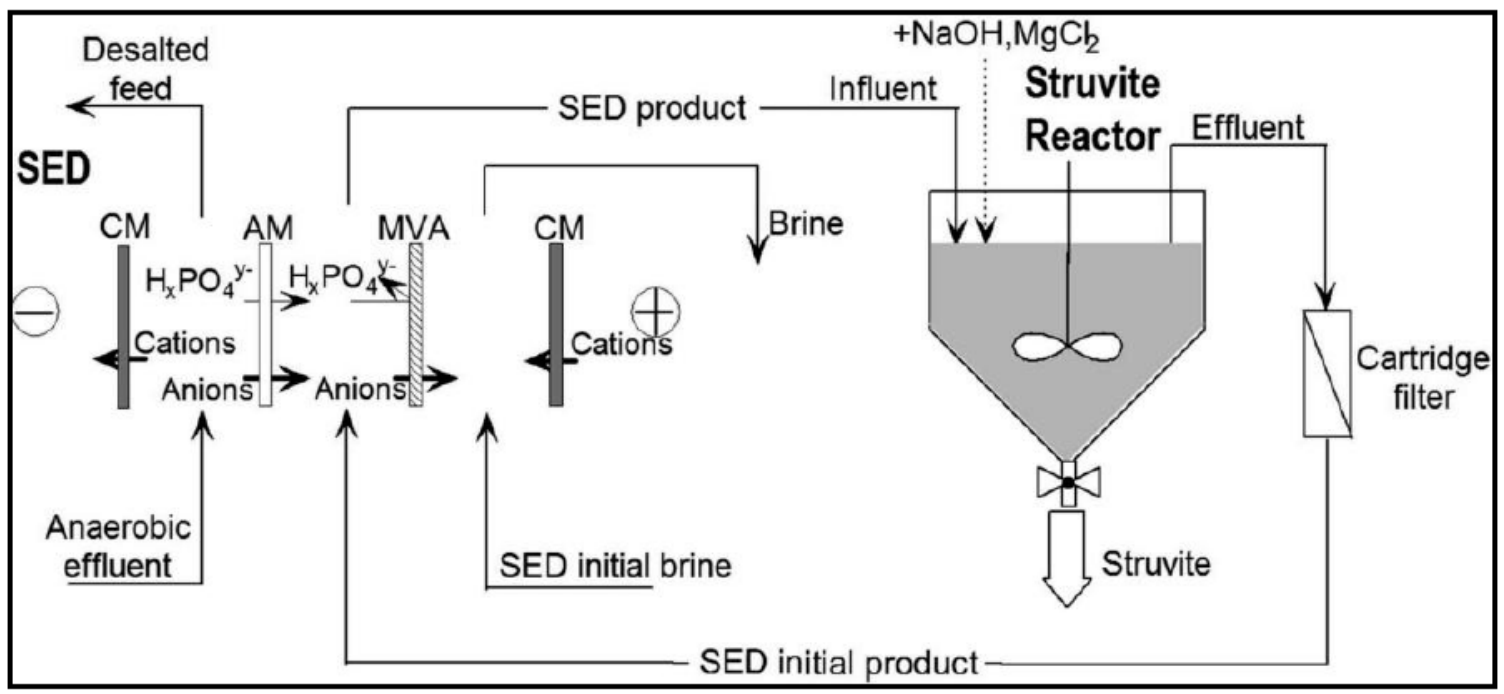

Figure 4: Flow scheme of Phosphate recovery from wastewater using selective electrodialysis (SED) [48]. Copyright (2013), Reprinted with permission from American Chemical Society.

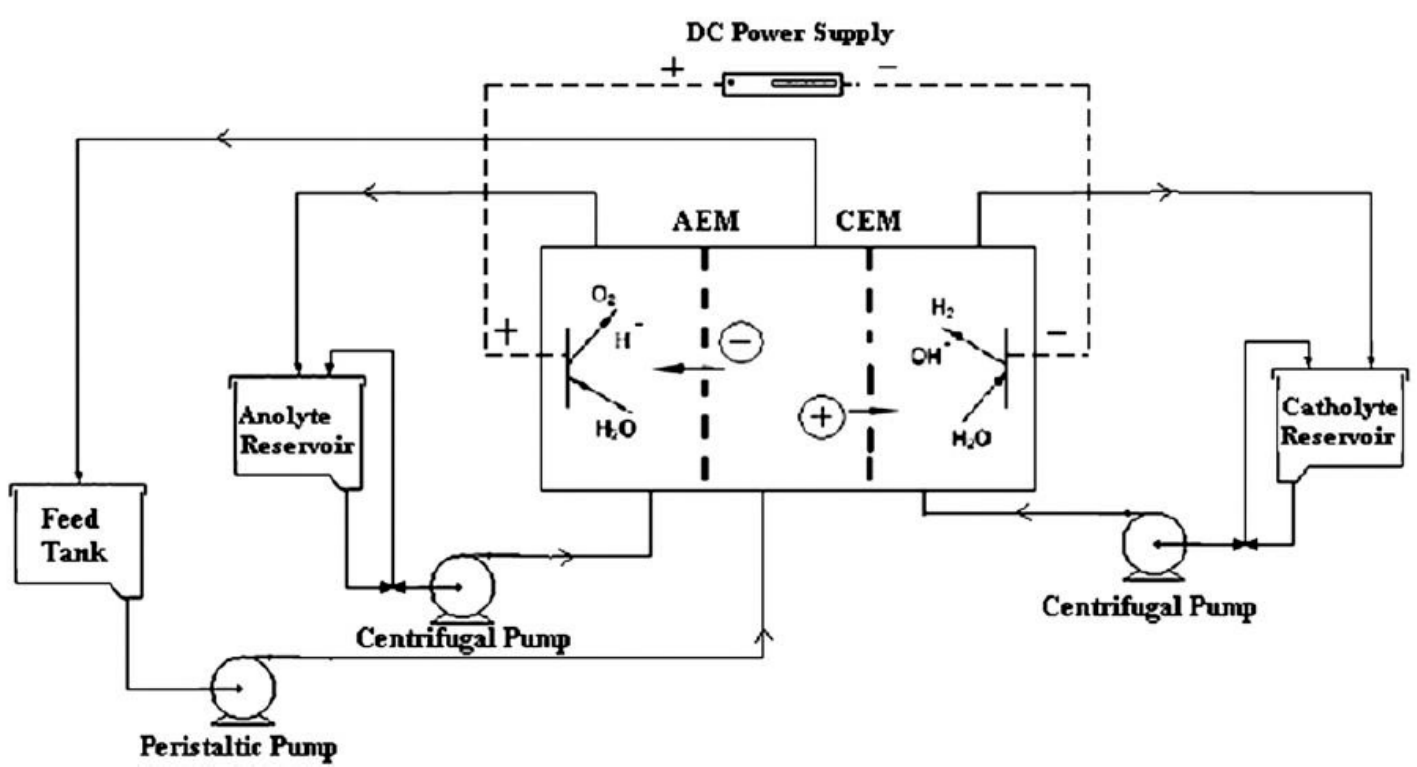

Figure 5: Batch mode experimental set-up of ED system (three-compartment cell) [141]. Copyright (2010), Reprinted from with permission from Elsevier.

efficiency, a cation exchange resin imported into dilute compartment to mitigate concentration polarization. The results indicate that a maximum $\mathrm{NaOH}$ recovery ratio of $75 \%$ was obtained for electrodialysis, and it is improved to $85 \%$ value by the introducing of cation exchange resin.

Besides, organic base, such as tetramethyl ammonium hydroxide (TMAH), which is often produced from photoresist developer wastewater, is another kind of hazardous material. It was recently recovered and recycled using electrodialysis in our group [15]. By this method, TMAH can be re-concentrated into the range of $7.45-8.33 \%$ mass concentration with a process cost about $36.4 \$$ t besides the recovered TMAH profits.

\subsection{Recovery of Acid}

Inorganic acids such as $\mathrm{HCl}, \mathrm{H}_{2} \mathrm{SO}_{4}, \mathrm{HNO}_{3}, \mathrm{HF}, \mathrm{HI}$ are often produced in industries of electroplating, metallurgy, biological fermentation and rare earth industry, etc. If the concentration is high $(>1 \mathrm{~mol} / \mathrm{L})$, the acid can be recovered by diffusion dialysis (DD). Due to the concentration limit of DD process, it is not proper for acid with low concentration and this waste with low acid concentration can be concentrated through 
electrodialysis and be recycled into the initial process. For examples, Kaoru et al. [142] used a threecompartment electrodialyser to treat the complex of hydriodic acid and iodine solution. In this process, Imoves from feed compartment through anion exchange membrane toward cathode compartment and oxidized to $\mathrm{I}_{2}$, at the same time, $\mathrm{H}^{+}$moves toward anode compartment simultaneously where $\mathrm{I}_{2}$ is reduced to $\mathrm{I}$. Hydriodic acid was also recovered by electroelectrodialysis (EED), a combination of electrolysis and electrodialysis with ion exchange membranes process [143]. Normally, EED mainly composes of two compartments: cathode compartment where reduction occur and anode compartment where oxidation occur, and one ion exchange membrane which was placed between two compartments allowing the passive of counter ions under the potential gradient. In this $\mathrm{HI}$ acid recovery process, the current efficiency is influenced by the temperature. At $293 \mathrm{~K}$, the current efficient was about $85.1 \%$; on the other hand, at $333 \mathrm{~K}$ it was about $82.5 \%$. Hydrochloric acid is also a widely used inorganic acid in the field of hydrometallurgical, pharmaceutical, food industry. However, the effluent that contains hydrochloric acid must be treated as their potential threat to environment. There are some works focusing on hydrochloric acid recovery from wasters [144, 145]. Our group [20] used integrated diffusion dialysis (DD) and conventional electrodialysis (CED) to recover hydrochloric acid from simulated chemosynthesis aluminum foils wastewater. In this method, initially the simulated wastewater was imputed into a spiral wound diffusion dialyser for recovering hydrochloric acid. Then the recovered low concentrations hydrochloric acid was reconcentrated by a conventional electrodialysis stack with a common configuration. To understand the compatibility and operational uniformity between DD and ED dialysate, flow rate and CED current were adjusted. The results indicate that high hydrochloric acid recovery rate of $74.9 \%$ was obtained with the energy consumption of $0.41 \mathrm{~kW}$ h and low aluminum leakage of $12.2 \%$. There are some other ED based useful acid reclamation processes from pickling wastewater [146-148], recovery of nitric acid [36, 149], especially, the recovery of metallic ion from pickling or plating waster as an independent process will be summarized in a separate section hereafter.

Besides inorganic acids, organic acid recovery using electrodialysis has also been studied for a long time. Citric acid, an organic acid, has been widely used for food industry, chemical and textile industry, environmental protection, cosmetics industry and pharmaceutical industry, etc. It is often synthesized using fermentation method with a subsequent addition of sulphuric acid and lime to clarify fermentation broths [150]. Due to this case, ED based separation process has been used as an alternatively to the conventional, such as bipolar membrane electrodialysis [151-156]. A comprehensive review has summarized the application of electrodialysis to the production of organic acids in detail [131].

\subsection{Recovery of Ionic Liquids (ILs)}

Ionic liquids (ILs), novel solvents, exhibit excellent properties, such as non-volatility, non-flammability, high electric conductivity, excellent catalytic activities and good phase separation performance. By virtue of these particular properties, ILs have been used for the extraction of biomass. However, the regeneration of biomass from ILs often produces large amounts of dilute waster with ILs. The disposal of ILs dilute wastewater may cause environmental issues due to their slow degradation and toxicity. ILs always consist of salts containing various heterocyclic cations and anions or other complex anions which could dissociate freely in aqueous solution. ED is often used as an optional process for the recovery of ILs. For examples, Trinh et al. [26] used it to recover an ionic liquid1-butyl3-methylimidazolium chloride [BMIM]Cl from a hydrolysis of lingocellulosic biomass. The results indicate that $64 \%$ ILs can be recovered with $63.5 \%$ current efficiency. The similar recovery was also conducted by Lu et al. [157]. Wang et al. [54] used this process for the recovering of 1-hexyl-3methylimidazolium chloride $([\mathrm{Hmim}] \mathrm{Cl})$ and 1-butyl-3methylimidazolium tetrafluoroborate ([Bmim]BF4). The results showed that the highest ILs reached to $85.2 \%$ and highest overall current efficiency reached to $80.9 \%$ with high specific energy consumption of $1350 \mathrm{~g} / \mathrm{kWh}$. Using this noble process, Haerens et al. [52] produced ILs of choline thiocyanate, choline acetate and choline dicyanamide from starting product choline chloride with a high current efficiency between $65 \%$ and $78 \%$.

\subsection{Recovery of Metals from Wastewater}

In chemical engineering industries such as hydrometallurgical, machinery manufacturing, electroplating, electronic industry and instrument manufacturing, there often produces large quantity of waste containing metal ions of chromium ( $\mathrm{Cr}$ ), copper $(\mathrm{Cu})$, nickel $(\mathrm{Ni})$, cadmium $(\mathrm{Cd})$, gold $(\mathrm{Au})$, and zinc (Zn). 
Chromium often exists as $\mathrm{Cr}$ (III) or $\mathrm{Cr}$ (VI) form in the wastewater produced from electroplating, leather tanning, cement and dyeing/fertilizer/photography industries. Chromium ion, especially hexavalent chromium $\mathrm{Cr}(\mathrm{VI})$ has been reported to be toxic to animals and humans and it is known as carcinogenic [158]. The direct discharge of the effluents would induce severe environmental problems. Gayathri et al. [159] used hybrid technology of ED and ion exchange to recover $\mathrm{Cr}(\mathrm{VI})$ from chrome plating wastewater. The efficiency of this method to remove and recover the chromium from the effluent was about $100 \%$ for the different modes of operation like 1) batch recirculation process; 2) batch recirculation process with continuous dipping; 3) continuous process. Chen et al. [45] used a two-stage ED (TSED) process for the recycling of $\mathrm{Cr}$ (VI) from electroplating wastewater (see Figure 6). In this process, the raw wastewater was concentrated by first stage ED at low $\mathrm{pH}$ condition. The concentrated stream was then adjusted to $\mathrm{pH} 8.5$ followed by treating with second stage ED which configuring monovalent anion permselective membrane and nonselective cation exchange membranes. The chromate in concentrated stream was concentrated up to $191 \%$ in the first stage and in the second stage; chloride was separated about $45 \%$ from $\mathrm{CrO}_{4}{ }^{2-}$. Nataraj et al. and Peng et al. [160, 161] also used ED to recover Cr (VI) from plating wastewaters. $\mathrm{Cr}$ (III) as another chromium in the environment is more stable and less toxic compare to $\mathrm{Cr}(\mathrm{VI})$. Lambert et al. [22, 35] used monovalent cation selective membrane for the selective recovery of $\mathrm{Cr}$ (III) from tanning process in the leather industry. The final results demonstrated that separation of trivalent chromium and sodium ion is possible.

To improve the corrosion resistance and provide decorative characteristics, electroplating and metal finishing processes often use several hazardous chemical and toxic compounds such as nickel. However, the effluent always contains nickel salts and organic additives that should be treated. ED as an excellent separation process has been used for the recovery of useful nickel from rinse water. For example, Benvenuti et al. [162] used ED to concentrate and extract nickel $(\mathrm{Ni})$ and its salts from the bright nickel electroplating process. In this extraction process, the recovery rate of nickel reached to $90 \mathrm{~mA} \mathrm{~A}^{-1} \mathrm{~h}^{-1} \mathrm{~cm}^{-2}$ with an energy consumption of $0.7 \mathrm{~kW} \mathrm{~h}$ for $1 \mathrm{~kg}$ $\mathrm{NiSO}_{4} \cdot \mathrm{H}_{2} \mathrm{O}$. Li et al. [163] also used ED to separate nickel ions from pent electroless nickel plating bath. ED combined with ion exchange has also been used to recover nickel from dilute solution [51, 53, 164, 165]. A highest recovery rate of $99 \%(\mathrm{Ni})$ was obtained by the using Dowex 50WX-2 resin [51]. After the treatment, the concentration of nickel in the process solution decreases from approximately $5 \mathrm{ppm}$ to less than the detection limit of the analysis (<20 ppb) [164]. Modified ED using special membranes such as liquid membrane and mono-valent selective membrane were also used for the selective recovery of nickel from electroplating industry $[166,167]$.

Besides chromium and nickel, lithium is a growing metal that is often used in production of glass and

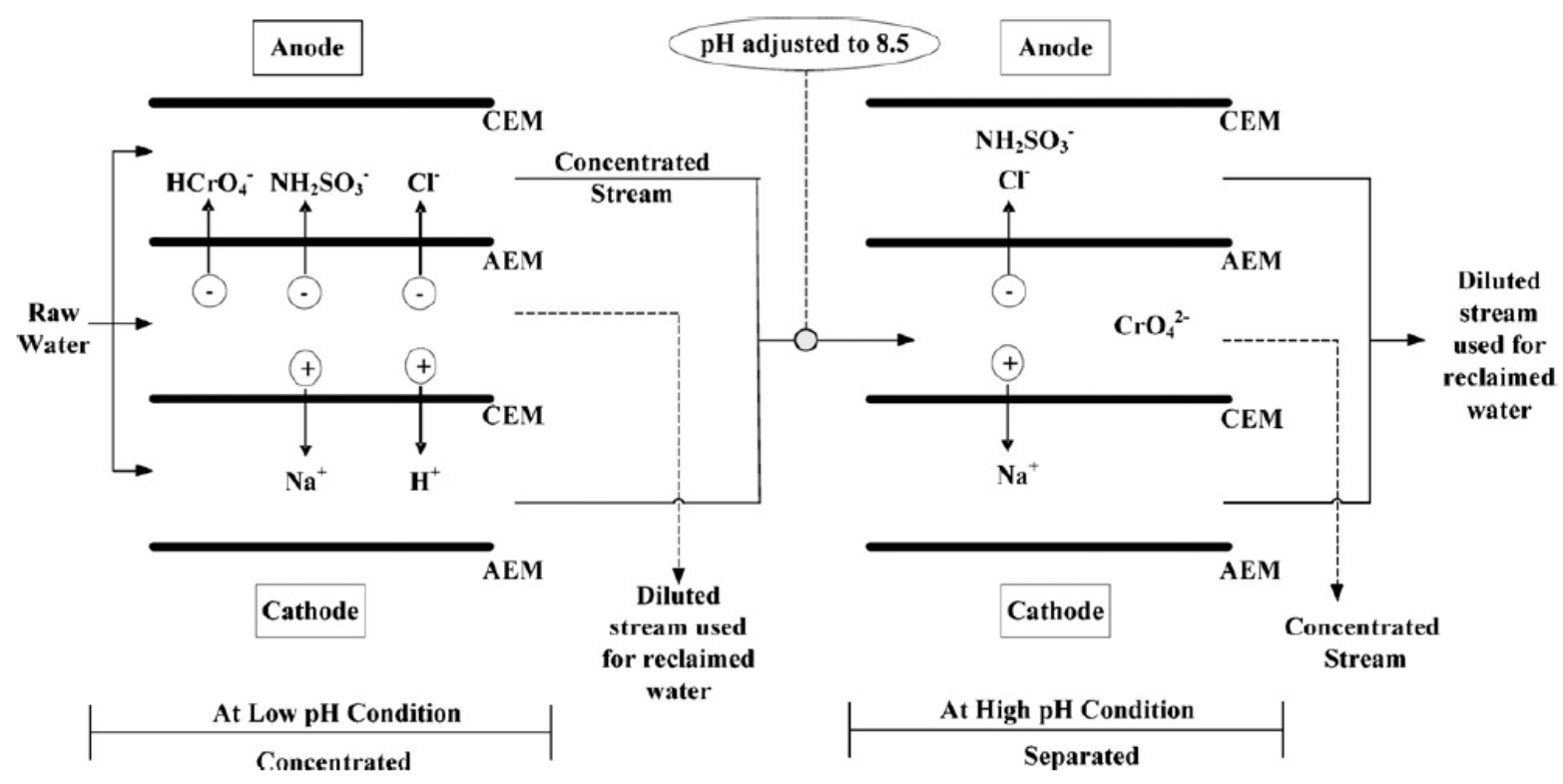

Figure 6: Schematic flow diagram for the TSED process to demonstrate the transportation of the major ions [45]. Copyright (2009), Reprinted from with permission from Elsevier. 
ceramic, air conditioning refrigeration systems, primary and second batteries, and nuclear energy production. Generally, lithium was extracted from lake brine or sweater instead of ore. Conventional extraction procedure of lithium requires high energy consumption and would induce sever environmental problem. ED is used as an optional process for the separation of lithium from lake brine, seawater and water. Recently, our group [19] used the integration of ED and bipolar membrane electrodialysis (BMED) for the production of $\mathrm{LiOH}$ from lake brine. In this process, the lake brine is treated with $\mathrm{Na}_{2} \mathrm{CO}_{3}$ to precipitate $\mathrm{Ca}$ and $\mathrm{Mg}$ ion followed by concentrating the effluent with low concentration lithium ion. The lithium ions are then extracted from concentrated brine by adding of $\mathrm{Na}_{2} \mathrm{CO}_{3}$ as $\mathrm{Li}_{2} \mathrm{CO}_{3}$ followed by treating the obtained $\mathrm{Li}_{2} \mathrm{CO}_{3}$ with BMED to produce $\mathrm{LiOH}$ (see Figure 7). The final results indicate that the concentration of lithium increased from $879 \mathrm{mg} / \mathrm{L}$ to 3157 and $3485 \mathrm{mg} / \mathrm{L}$ respectively, for two operating voltage of $10 \mathrm{~V}$ and $15 \mathrm{~V}$, as well as a high purity of ca. $98 \% \mathrm{Li}_{2} \mathrm{CO}_{3}$ powder was obtained by this process. Lithium, an alkali metal abundantly present in sea water, was also recovered by ED using liquid membranes [41-43, 168]. This modified ED involves the using of ionic-liquid-impregnated organic membrane (IL-i-OM) through which only the $\mathrm{Li}$ ions in seawater can permeate through.

There are several other ED based separation processes to recover environment pollutants but useful metals from wasters, such as the isolation and reclamation of $\mathrm{Cu}(\mathrm{II})$ [169-173], $\mathrm{Pb}$ (II) [174-176], $\mathrm{Zn}$ [177], Mn [57, 178], Na, K-Salt [14, 23, 37, 39, 44, 179], $\mathrm{Au}$ (III) [56], dyes and mineral salts [180], etc. They will not be discussed in detail here due to the page limits.

\section{SUMMARY AND PERSPECTIVE}

This contribution summarizes up-to-date synthetic tactics for the preparation of ion-exchange materials and their applications for electrodialysis related processes from the literature. We feel that most of the upcoming progresses in the area will come from those developers or users that will look at these technologies as tools to cope with their specific treatment requirements. But it should be given emphasis that preparation of ion exchange membranes or materials is the most crucial. IEMs with high performance are important polymeric materials and used in ED for different applications. The main driving force for the development of new IEMs with improved properties is to make those applications more effective.

Actually, the performance of membranes is determined by its properties and separation abilities. IEMs can be designed and prepared by a number of tactics varying from basic polymer reactions to innovative nanotechnology via molecular design and architectural tailoring of composite materials.
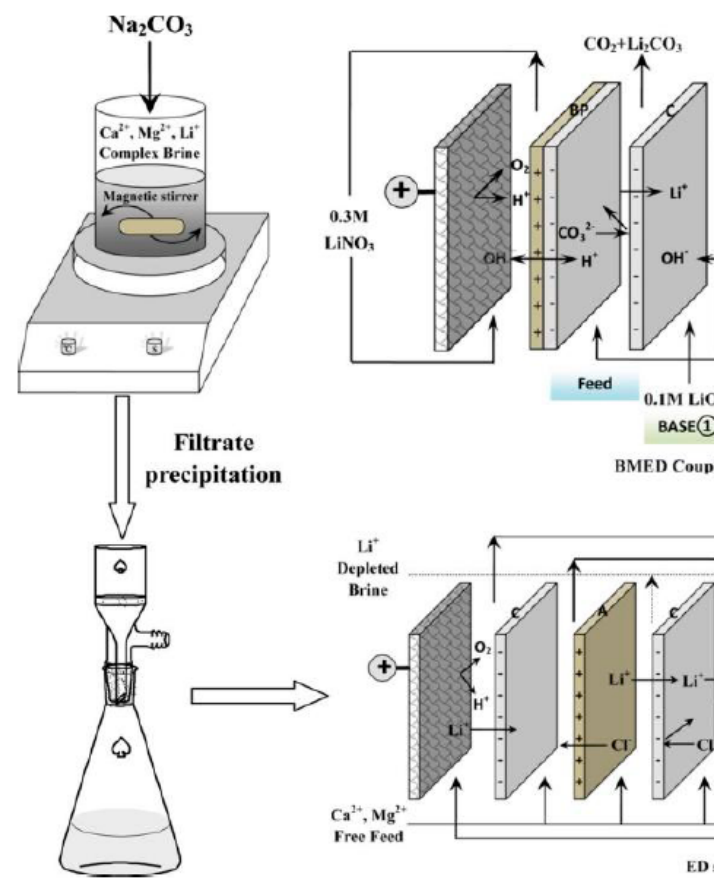
Besides the preparation of IEMs, the technical and commercial relevance of the IEM-based ED processes should also be taken into account. As evaluated by Strathmann [181], some of the ED applications can be considered as state-of-the-art technology, such as the applications using conventional electrodialysis, production of pure water using continuous electrodeionization and some specific applications using bipolar membranes, such as production of organic acid from the fermentation broth or recovery of $\mathrm{HF}$ and $\mathrm{HNO}_{3}$ from a waste stream generated by neutralization of a steel pickling bath. In some applications, ED processes provide higher quality products or are more environmentally friendly and will therefore be used in spite of some drawback such as operation cost. Also, increasing costs of raw materials and environmental awareness have expanded the application of ED.

However, the targeted properties of IEMs have to be set up to fulfill the membrane requirements for specific applications, and appropriate synthesis routes for IEMs towards the goals should be specified accordingly. Besides the material development, the ED system design and their operation optimization should also be further developed. In the ED based application of the IEMs, new systems to bring down the energy consumption and production cost require more progress.

\section{ACKNOWLEDGEMENTS}

The financial support from the National Natural Science Foundation of China (nos.51273185, 21476220), National High Technology Research and Development Program 863 (2012AA03A608), and Chinese government (through Chinese Government Scholarship - University Postgraduate Program (CGSUPP)) is gratefully acknowledged.

\section{REFERENCES}

[1] Taeger A, Vogel C, Lehmann D, Jehnichen D, Komber $H$, Meier-Haack J, Ochoa NA, Nunes SP, Peinemann KV. Ion exchange membranes derived from sulfonated polyaramides. Reactive and Functional Polymers 2003; 57: 77-92. http://dx.doi.org/10.1016/j.reactfunctpolym.2003.10.001

[2] Meier-Haack J, Taeger A, Vogel C, Schlenstedt K, Lenk W, Lehmann D. Membranes from sulfonated block copolymers for use in fuel cells. Separation and Purification Technology 2005; 41: 207-220.

http://dx.doi.org/10.1016/j.seppur.2004.07.018

[3] Juda W, McRae WA. Coherent ion-exchange gels and membranes. Journal of the American Chemical Society 1950; 72: 1044-1044.

\section{http://dx.doi.org/10.1021/ja01158a528}

[4] Winger AG, Bodamer GW, Kunin R. Some electrochemical properties of new synthetic ion exchange membranes. Journal of The Electrochemical Society 1953; 100: 178-184. http://dx.doi.org/10.1149/1.2781103
[5] Nishiwaki T. Concentration of electrolytes prior to evaporation with an electro-membrane process, in: R.F. Lacey, S. Loch (Eds.), Industrial Process with Membranes. Wiley-Interscience, New York 1972.

[6] Mihara K. Polarity reversing electrode units and electrical switching means therefor, U.S. Patent 3,453,201, (1979).

[7] Grot WG. Laminates of support material and fluorinated polymer containing pendant side chains containing sulfonyl groups, U.S. Patent 3,770,567, (1973).

[8] Chlanda FP, Lee LT, Liu K-J. Bipolar membranes and method of making same, in, U.S. Patent 1978.

[9] Pourcelly G, Gavach C. Electrodialysis water splittingapplication of electrodialysis with bipolar membranes, in: A.J.B. Kemperman (Ed.), Handbook on Bipolar Membrane Technology. Twente University Press, Enschede 2000; pp. 17-46.

[10] Xu T. Ion exchange membranes: State of their development and perspective. Journal of Membrane Science 2005; 263: 129 .

http://dx.doi.org/10.1016/j.memsci.2005.05.002

[11] Klaysom C, Ladewig BP, Lu GQM, Wang L. Recent Advances in Ion Exchange Membranes for Desalination Applications Functional Nanostructured Materials and Membranes for Water Treatment 2013; 125-161.

[12] Mondor M, Masse L, Ippersiel D, Lamarche F, Masse DI. Use of electrodialysis and reverse osmosis for the recovery and concentration of ammonia from swine manure. Bioresource Technology 2008; 99: 7363-7368.

http://dx.doi.org/10.1016/j.biortech.2006.12.039

[13] Ippersiel D, Mondor M, Lamarche F, Tremblay F, Dubreuil J, Masse L. Nitrogen potential recovery and concentration of ammonia from swine manure using electrodialysis coupled with air stripping. Journal of Environmental Management 2012; 95: S165-S169.

http://dx.doi.org/10.1016/j.jenvman.2011.05.026

[14] Jiang C, Wang Y, Zhang Z, Xu T. Electrodialysis of concentrated brine from RO plant to produce coarse salt and freshwater. Journal of Membrane Science 2014; 450: 323330.

http://dx.doi.org/10.1016/j.memsci.2013.09.020

[15] Wang Y, Zhang Z, Jiang C, Xu T. Electrodialysis Process for the Recycling and Concentrating of Tetramethylammonium Hydroxide (TMAH) from Photoresist Developer Wastewater. Industrial \& Engineering Chemistry Research 2013; 52: 18356-18361.

http://dx.doi.org/10.1021/ie4023995

[16] Yan H, Xue S, Wu C, Wu Y, Xu T. Separation of $\mathrm{NaOH}$ and $\mathrm{NaAl}(\mathrm{OH})_{4}$ in alumina alkaline solution through diffusion dialysis and electrodialysis. Journal of Membrane Science 2014; 469: 436-446.

http://dx.doi.org/10.1016/j.memsci.2014.07.002

[17] Wang XL, Wang YM, Zhang X, Feng HY, Li CR, Xu TW. Phosphate Recovery from Excess Sludge by Conventional Electrodialysis (CED) and Electrodialysis with Bipolar Membranes (EDBM). Industrial \& Engineering Chemistry Research 2013; 52: 15896-15904. http://dx.doi.org/10.1021/ie4014088

[18] Ren HY, Sun FB, Shi SY, Cong W. Ceramic membrane pretreatment of monosodium glutamate isoelectric supernatant to facilitate $\left(\mathrm{NH}_{4}\right)_{2} \mathrm{SO}_{4}$ recovery by electrodialysis. Journal of Chemical Technology and Biotechnology 2008; 83: 1027-1033. http://dx.doi.org/10.1002/jctb.1909

[19] Jiang C, Wang $Y$, Wang $Q$, Feng $H, X u$ T. Production of Lithium Hydroxide from Lake Brines through ElectroElectrodialysis with Bipolar Membranes (EEDBM). Industrial \& Engineering Chemistry Research 2014; 53: 6103-6112. http://dx.doi.org/10.1021/ie404334s 
[20] Zhang X, Li CR, Wang XL, Wang YM, Xu TW. Recovery of hydrochloric acid from simulated chemosynthesis aluminum foils wastewater: An integration of diffusion dialysis and conventional electrodialysis Journal of Membrane Science 2012; 409: 257-263.

http://dx.doi.org/10.1016/j.memsci.2012.03.062

[21] Lee HJ, Oh SJ, Moon SH. Recovery of ammonium sulfate from fermentation waste by electrodialysis. Water Res 2003; 37: 1091-1099.

http://dx.doi.org/10.1016/S0043-1354(02)00451-7

[22] Lambert J, Avila-Rodriguez M, Durand G, Rakib M. Separation of sodium ions from trivalent chromium by electrodialysis using monovalent cation selective membranes. Journal of Membrane Science 2006; 280: 219225.

http://dx.doi.org/10.1016/j.memsci.2006.01.021

[23] Turek $\mathrm{M}$. Recovery of $\mathrm{NaCl}$ from saline mine water in an electrodialysis-evaporation system. Chemical PapersChemicke Zvesti 2003; 57: 50-52.

[24] Wee YJ, Yun JS, Lee YY, Zeng AP, Ryu HW. Recovery of lactic acid by repeated batch electrodialysis and lactic acid production using electrodialysis wastewater. Journal of Bioscience and Bioengineering 2005; 99: 104-108.

http://dx.doi.org/10.1263/jbb.99.104

[25] Lee EG, Moon SH, Chang YK, Yoo IK, Chang HN. Lactic acid recovery using two-stage electrodialysis and its modelling. Journal of Membrane Science 1998; 145: 53-66. http://dx.doi.org/10.1016/S0376-7388(98)00065-9

[26] Trinh LTP, Lee YJ, Lee JW, Bae HJ, Lee HJ. Recovery of an ionic liquid $\mathrm{BMIM} \mathrm{Cl}$ from a hydrolysate of lignocellulosic biomass using electrodialysis. Separation and Purification Technology 2013; 120: 86-91.

http://dx.doi.org/10.1016/j.seppur.2013.09.025

[27] Kameda T, Fukushima S, Shoji C, Grause G, Yoshioka T. Electrodialysis for $\mathrm{NaCl} / \mathrm{EG}$ solution using ion-exchange membranes. Journal of Material Cycles and Waste Management 2013; 15: 111-114.

http://dx.doi.org/10.1007/s10163-012-0098-1

[28] Roblet C, Doyen A, Amiot J, Pilon G, Marette A, Bazinet L. Enhancement of glucose uptake in muscular cell by soybean charged peptides isolated by electrodialysis with ultrafiltration membranes (EDUF): Activation of the AMPK pathway. Food Chem 2014; 147: 124-130.

http://dx.doi.org/10.1016/j.foodchem.2013.09.108

[29] Roblet C, Doyen A, Amiot J, Bazinet L. Impact of $\mathrm{pH}$ on ultrafiltration membrane selectivity during electrodialysis with ultrafiltration membrane (EDUF) purification of soy peptides from a complex matrix. Journal of Membrane Science 2013; 435: 207-217. http://dx.doi.org/10.1016/j.memsci.2013.01.045

[30] Poulin J-F, Amiot J, Bazinet L. Impact of Feed Solution Flow Rate on Peptide Fractionation by Electrodialysis with Ultrafiltration Membrane. Journal of agricultural and food chemistry 2008; 56: 2007-2011. http://dx.doi.org/10.1021/jf072813d

[31] Poulin JF, Amiot J, Bazinet L. Simultaneous separation of acid and basic bioactive peptides by electrodialysis with ultrafiltration membrane. J Biotechnol 2006; 123: 314-328. http://dx.doi.org/10.1016/j.jbiotec.2005.11.016

[32] Poulin JF, Amiot J, Bazinet L. Improved peptide fractionation by electrodialysis with ultrafiltration membrane: Influence of ultrafiltration membrane stacking and electrical field strength. Journal of Membrane Science 2007; 299: 83-90. http://dx.doi.org/10.1016/j.memsci.2007.04.024

[33] Sun GF, Xu JL. Treatment of Waste Phosphoric Acid Containing Metal lons by Electrodialysis, in: K.S. Thaung (Ed.) Future Material Research and Industry Application, Pts 1 and 2 2012; pp. 1228-1231.
[34] Tor A, Büyükerkek T, Çengelolu Y, Ersöz M. Simultaneous recovery of $\mathrm{Cr}(\mathrm{III})$ and $\mathrm{Cr}(\mathrm{VI})$ from the aqueous phase with ion-exchange membranes. Desalination 2005; 171: 233-241. http://dx.doi.org/10.1016/j.desal.2004.02.106

[35] Lambert J, Rakib M, Durand G, Avila-Rodriguez M. Treatment of solutions containing trivalent chromium by electrodialysis. Desalination 2006; 191: 100-110.

http://dx.doi.org/10.1016/j.desal.2005.06.035

[36] Kim KW, Hyun JT, Lee KY, Lee EH, Chung DY, Moon JK. Evaluation of recovery characteristic of acidic and alkaline solutions from $\mathrm{NaNO}_{3}$ using conventional electrodialysis and electrodialysis with bipolar membranes. Korean J Chem Eng 2013; 30: 1760-1769.

http://dx.doi.org/10.1007/s11814-013-0089-5

[37] Kim HH, Kang SH, Chang YK. Recovery of Potassium Clavulanate from Fermentation Broth by Ion Exchange Chromatography and Desalting Electrodialysis. Biotechnology and Bioprocess Engineering 2009; 14: 803810. http://dx.doi.org/10.1007/s12257-008-0161-x

[38] Husson E, Araya-Farias M, Desjardins $Y$, Bazinet $L$. Selective anthocyanins enrichment of cranberry juice by electrodialysis with ultrafiltration membranes stacked. Innovative Food Science \& Emerging Technologies 2013; 17: 153-162.

http://dx.doi.org/10.1016/j.ifset.2012.09.011

[39] Habe H, Fukuoka T, Kitamoto D, Sakaki K. Application of electrodialysis to glycerate recovery from a glycerol containing model solution and culture broth. Journal of Bioscience and Bioengineering 2009; 107: 425-428. http://dx.doi.org/10.1016/i.jbiosc.2008.12.008

[40] Firdaous L, Dhulster P, Amiot J, Gaudreau A, Lecouturier D, Kapel R, Lutin F, Vezina LP, Bazinet L. Concentration and selective separation of bioactive peptides from an alfalfa white protein hydrolysate by electrodialysis with ultrafiltration membranes. Journal of Membrane Science 2009; 329: 6067. http://dx.doi.org/10.1016/j.memsci.2008.12.012

[41] Hoshino T. Lithium Recovery from Seawater by Electrodialysis using Ionic Liquid-based Membrane Technology. Lithium-Ion Batteries 2014; 58: 173-177.

[42] Hoshino T. Preliminary studies of lithium recovery technology from seawater by electrodialysis using ionic liquid membrane. Desalination 2013; 317: 11-16.

http://dx.doi.org/10.1016/j.desal.2013.02.014

[43] Hoshino T. Development of technology for recovering lithium from seawater by electrodialysis using ionic liquid membrane. Fusion Eng Des 2013; 88: 2956-2959.

http://dx.doi.org/10.1016/j.fusengdes.2013.06.009

[44] Fidaleo M, Moresi M. Modeling of sodium acetate recovery from aqueous solutions by electrodialysis. Biotechnol Bioeng 2005; 91: 556-568. http://dx.doi.org/10.1002/bit.20413

[45] Chen SS, Li CW, Hsu HD, Lee PC, Chang YM, Yang $\mathrm{CH}$. Concentration and purification of chromate from electroplating wastewater by two-stage electrodialysis processes. Journal of hazardous materials 2009; 161: 10751080.

http://dx.doi.org/10.1016/j.jhazmat.2008.04.106

[46] Frenzel I, Holdik H, Stamatialis DF, Pourcelly G, Wessling A. Chromic acid recovery by electro-electrodialysis - I. Evaluation of anion-exchange membrane Journal of Membrane Science 2005; 261: 49-57. http://dx.doi.org/10.1016/j.memsci.2005.03.031

[47] Eszter M, Matild E, Kornelia K, Nandor N, Jeno F, Katalin BB. Utilization of electrodialysis for galacturonic acid recovery. Desalination 2009; $241: 81-85$. http://dx.doi.org/10.1016/j.desal.2008.01.059 
[48] Zhang Y, Desmidt E, Van Looveren A, Pinoy L, Meesschaert B, Van der Bruggen B. Phosphate Separation and Recovery from Wastewater by Novel Electrodialysis. Environ Sci Technol 2013; 47: 5888-5895.

http://dx.doi.org/10.1021/es4004476

[49] Zelic B, Hadolin M, Bauman D, Vasic-Racki D. Recovery and purification of rosmarinic acid from rosemary using electrodialysis. Acta Chimica Slovenica 2005; 52: 126-130.

[50] Frenzel I, Holdik H, Stamatialis DF, Pourcelly G, Wessling A. Chromic acid recovery by electro-electrodialysis II. Pilot scale process, development, and optimization. Separation and Purification Technology 2005; 47: 27-35.

http://dx.doi.org/10.1016/j.seppur.2005.06.002

[51] Dzyaz'ko YS, Rozwestvenskaya LM, Pal'chik AV. Recovery of nickel ions from dilute solutions by electrodialysis combined with ion exchange. Russian Journal of Applied Chemistry 2005; 78: 414-421. http://dx.doi.org/10.1007/s11167-005-0307-y

[52] Haerens K, De Vreese P, Matthijs E, Pinoy L, Binnemans K, Van der Bruggen B. Production of ionic liquids by electrodialysis. Separation and Purification Technology 2012; 97: 90-95.

http://dx.doi.org/10.1016/j.seppur.2012.02.017

[53] Dzyazko YS, Belyakov VN. Purification of a diluted nickel solution containing nickel by a process combining ion exchange and electrodialysis. Desalination 2004; 162: 179189.

http://dx.doi.org/10.1016/S0011-9164(04)00041-4

[54] Wang XL, Nie Y, Zhang XP, Zhang SJ, Li JW. Recovery of ionic liquids from dilute aqueous solutions by electrodialysis. Desalination 2012; 285: 205-212.

http://dx.doi.org/10.1016/j.desal.2011.10.003

[55] Tanaka Y, Moon S-H, Nikonenko VV, Xu T. Ion-Exchange Membranes. International Journal of Chemical Engineering 2012; 2012: 3.

[56] Sadyrbaeva TZ. Gold(III) recovery from non-toxic electrolytes using hybrid electrodialysis-electrolysis process. Separation and Purification Technology 2012; 86: 262-265.

http://dx.doi.org/10.1016/j.seppur.2011.10.007

[57] Sadyrbaeva TZ. Hybrid liquid membrane - Electrodialysis process for extraction of manganese(II). Desalination 2011; 274: 220-225.

http://dx.doi.org/10.1016/j.desal.2011.02.022

[58] Park H-M, Park S-G, Hwang CW, Hwang TS. Effect of aminating agents on the permselectivity for nitrate of aminated poly(vinyl benzylchloride-co-styrene-co-hydroxy ethylacrylate) membranes. Journal of Membrane Science 2013; 447: 253-259. http://dx.doi.org/10.1016/j.memsci.2013.06.058

[59] Sharma S, Dinda M, Sharma CR, Ghosh PK. A safer route for preparation of anion exchange membrane from interpolymer film and performance evaluation in electrodialytic application. Journal of Membrane Science 2014; 459: 122131.

http://dx.doi.org/10.1016/j.memsci.2014.02.011

[60] Bertran O, Armelin E, Estrany F, Gomes A, Torras J, Alemán C. Poly (2-thiophen-3-yl-malonic acid), a polythiophene with two carboxylic acids per repeating unit. The Journal of Physical Chemistry B 2010; 114: 6281-6290.

http://dx.doi.org/10.1021/jp1006796

[61] Nagarale R, Gohil G, Shahi VK, Rangarajan R. Preparation and electrochemical characterization of sulfonated polysulfone cation-exchange membranes: Effects of the solvents on the degree of sulfonation. Journal of Applied Polymer Science 2005; 96: 2344-2351.

http://dx.doi.org/10.1002/app.21630

[62] Asquith BM, Meier-Haack J, Vogel C, Butwilowski W, Ladewig BP. Side-chain sulfonated copolymer cation exchange membranes for electro-driven desalination applications. Desalination 2013; 324: 93-98.

http://dx.doi.org/10.1016/j.desal.2013.05.023

[63] Klaysom C, Ladewig BP, Lu GQM, Wang L. Preparation and characterization of sulfonated polyethersulfone for cationexchange membranes. Journal of Membrane Science 2011; 368: 48-53.

http://dx.doi.org/10.1016/j.memsci.2010.11.006

[64] Klaysom C, Moon S-H, Ladewig BP, Lu GQM, Wang L. Preparation of porous ion-exchange membranes (IEMs) and their characterizations. Journal of Membrane Science 2011; 371: 37-44.

http://dx.doi.org/10.1016/i.memsci.2011.01.008

[65] Mabrouk W, Ogier L, Vidal S, Sollogoub C, Matoussi F, Fauvarque JF. Ion exchange membranes based upon crosslinked sulfonated polyethersulfone for electrochemical applications. Journal of Membrane Science 2014; 452: 263270.

http://dx.doi.org/10.1016/j.memsci.2013.10.006

[66] Park AM, Turley FE, Wycisk RJ, Pintauro PN. Electrospun and Cross-Linked Nanofiber Composite Anion Exchange Membranes. Macromolecules 2014; 47: 227-235. http://dx.doi.org/10.1021/ma401932h

[67] Balster J, Krupenko O, Punt I, Stamatialis D, Wessling M. Preparation and characterisation of monovalent ion selective cation exchange membranes based on sulphonated poly(ether ether ketone). Journal of Membrane Science 2005; 263: 137-145.

http://dx.doi.org/10.1016/i.memsci.2005.04.019

[68] Gohil GS, Nagarale RK, Binsu VV, Shahi VK. Preparation and characterization of monovalent cation selective sulfonated poly(ether ether ketone) and poly(ether sulfone) composite membranes. Journal of Colloid and Interface Science 2006; 298: 845-853.

http://dx.doi.org/10.1016/.j.jcis.2005.12.069

[69] Kerres J, Cui W, Disson R, Neubrand W. Development and characterization of crosslinked ionomer membranes based upon sulfinated and sulfonated PSU crosslinked PSU blend membranes by disproportionation of sulfinic acid groups. Journal of Membrane Science 1998; 139: 211-225. http://dx.doi.org/10.1016/S0376-7388(97)00253-6

[70] Cui W, Kerres J, Eigenberger G. Development and characterization of ion-exchange polymer blend membranes. Separation and Purification Technology 1998; 14: 145-154. http://dx.doi.org/10.1016/S1383-5866(98)00069-0

[71] Wu L, Xu T, Yang W. Fundamental studies of a new series of anion exchange membranes: Membranes prepared through chloroacetylation of poly(2,6-dimethyl-1,4-phenylene oxide) (PPO) followed by quaternary amination. Journal of Membrane Science 2006; 286: 185-192.

http://dx.doi.org/10.1016/j.memsci.2006.09.035

[72] Xu T, Zha F. Fundamental studies on a new series of anion exchange membranes: effect of simultaneous aminationcrosslinking processes on membranes ion-exchange capacity and dimensional stability. Journal of Membrane Science 2002; 199: 203-210. http://dx.doi.org/10.1016/S0376-7388(02)00261-2

[73] Tongwen $X$, Weihua $Y$. Fundamental studies of a new series of anion exchange membranes: membrane preparation and characterization. Journal of Membrane Science 2001; 190: 159-166.

http://dx.doi.org/10.1016/S0376-7388(01)00434-3

[74] Tongwen X, Weihua $\mathrm{Y}$, Binglin $\mathrm{H}$. Ionic conductivity threshold in sulfonated poly (phenylene oxide) matrices: a combination of three-phase model and percolation theory. Chemical Engineering Science 2001; 56: 5343-5350. http://dx.doi.org/10.1016/S0009-2509(01)00242-1

[75] Johnson B, Yilgör I, Tran C, Iqbal M, Wightman J, Lloyd D, McGrath J. Synthesis and characterization of sulfonated poly 
(acrylene ether sulfones). Journal of Polymer Science: Polymer Chemistry Edition 1984; 22: 721-737. http://dx.doi.org/10.1002/pol.1984.170220320

[76] Liu B, Robertson GP, Kim D-S, Sun X, Jiang Z, Guiver MD. Enhanced thermo-oxidative stability of sulfophenylated poly (ether sulfone)s. Polymer 2010; 51: 403-413. http://dx.doi.org/10.1016/j.polymer.2009.12.014

[77] Omichi H, Chundury D, Stannett V. Electrical and other properties of mutual radiation-induced methacrylic acid grafted polyethylene films. Journal of Applied Polymer Science 1986; 32: 4827-4836.

http://dx.doi.org/10.1002/app.1986.070320505

[78] Kostov GK, Matsuda O, Machi S, Tabata Y. Radiation synthesis of ion-exchange carboxylic fluorine containing membranes. Journal of Membrane Science 1992; 68: 133140.

http://dx.doi.org/10.1016/0376-7388(92)80156-E

[79] Choi E-Y, Strathmann H, Park J-M, Moon S-H. Characterization of non-uniformly charged ion-exchange membranes prepared by plasma-induced graft polymerization. Journal of Membrane Science 2006; 268: 165-174.

http://dx.doi.org/10.1016/j.memsci.2005.06.052

[80] Choi S-H, Han Jeong Y, Jeong Ryoo J, Lee K-P. Desalination by electrodialysis with the ion-exchange membrane prepared by radiation-induced graft polymerization. Radiation Physics and Chemistry 2001; 60: 503-511.

http://dx.doi.org/10.1016/S0969-806X(00)00397-2

[81] Tzanetakis N, Varcoe J, Slade R, Scott K. Salt splitting with radiation grafted PVDF anion-exchange membrane. Electrochemistry Communications 2003; 5: 115-119. http://dx.doi.org/10.1016/S1388-2481(02)00554-4

[82] Hensley JE, Way JD. Synthesis and characterization of perfluorinated carboxylate/sulfonate ionomer membranes for separation and solid electrolyte applications. Chemistry of Materials 2007; 19: 4576-4584.

http://dx.doi.org/10.1021/cm070138h

[83] Singh S, Jasti A, Kumar M, Shahi VK. A green method for the preparation of highly stable organic-inorganic hybrid anionexchange membranes in aqueous media for electrochemical processes. Polymer Chemistry 2010; 1: 1302.

http://dx.doi.org/10.1039/c0py00084a

[84] Nagarale RK, Shahi VK, Rangarajan R. Preparation of polyvinyl alcohol-silica hybrid heterogeneous anionexchange membranes by sol-gel method and their characterization. Journal of Membrane Science 2005; 248: 37-44.

http://dx.doi.org/10.1016/j.memsci.2004.09.025

[85] Klaysom C, Marschall R, Wang L, Ladewig BP, Lu GQM. Synthesis of composite ion-exchange membranes and their electrochemical properties for desalination applications. Journal of Materials Chemistry 2010; 20: 4669. http://dx.doi.org/10.1039/b925357b

[86] Klaysom C, Marschall R, Moon S-H, Ladewig BP, Lu GQM, Wang L. Preparation of porous composite ion-exchange membranes for desalination application. Journal of Materials Chemistry 2011; 21: 7401.

http://dx.doi.org/10.1039/c0jm04142d

[87] Klaysom C, Moon SH, Ladewig BP, Lu GQ, Wang L. The effects of aspect ratio of inorganic fillers on the structure and property of composite ion-exchange membranes. Journal of Colloid and Interface Science 2011; 363: 431-439. http://dx.doi.org/10.1016/j.jcis.2011.07.071

[88] Klaysom C, Moon S-H, Ladewig BP, Lu GQM, Wang L. The Influence of Inorganic Filler Particle Size on Composite IonExchange Membranes for Desalination. The Journal of Physical Chemistry C 2011; 115: 15124-15132.

http://dx.doi.org/10.1021/jp112157z
[89] Zuo X, Shi W, Tian Z, Yu S, Wang S, He J. Desalination of water with a high degree of mineralization using SiO2/PVDF membranes. Desalination 2013; 311: 150-155. http://dx.doi.org/10.1016/i.desal.2012.11.034

[90] Zuo X, Yu S, Xu X, Xu J, Bao R, Yan X. New PVDF organicinorganic membranes: The effect of $\mathrm{SiO} 2$ nanoparticles content on the transport performance of anion-exchange membranes. Journal of Membrane Science 2009; 340: 206213.

\section{http://dx.doi.org/10.1016/j.memsci.2009.05.032}

[91] Zuo X, Yu S, Xu X, Bao R, Xu J, Qu W. Preparation of organic-inorganic hybrid cation-exchange membranes via blending method and their electrochemical characterization. Journal of Membrane Science 2009; 328: 23-30. http://dx.doi.org/10.1016/j.memsci.2008.08.012

[92] Khodabakhshi A, Madaeni S, Hosseini S. Comparative studies on morphological, electrochemical, and mechanical properties of S-polyvinyl chloride based heterogeneous cation-exchange membranes with different resin ratio loading. Industrial \& Engineering Chemistry Research 2010; 49: 8477-8487.

http://dx.doi.org/10.1021/ie9014205

[93] Shah BG, Shahi VK, Thampy SK, Rangarajan R, Ghosh PK Comparative studies on performance of interpolymer and heterogeneous ion-exchange membranes for water desalination by electrodialysis. Desalination 2005; 172: 257265.

http://dx.doi.org/10.1016/i.desal.2004.06.204

[94] Hosseini SM, Koranian P, Gholami A, Madaeni SS Moghadassi AR, Sakinejad P, Khodabakhshi AR. Fabrication of mixed matrix heterogeneous ion exchange membrane by multiwalled carbon nanotubes: Electrochemical characterization and transport properties of mono and bivalent cations. Desalination 2013; 329: 62-67. http://dx.doi.org/10.1016/..desal.2013.09.007

[95] Hosseini SM, Jeddi F, Nemati M, Madaeni SS, Moghadassi AR. Electrodialysis heterogeneous anion exchange membrane modified by PANI/MWCNT composite nanoparticles: Preparation, characterization and ionic transport property in desalination. Desalination 2014; 341 : 107-114.

http://dx.doi.org/10.1016/j.desal.2014.03.001

[96] Hosseini SM, Madaeni SS, Khodabakhshi AR, Zendehnam A. Preparation and surface modification of PVC/SBR heterogeneous cation exchange membrane with silver nanoparticles by plasma treatment. Journal of Membrane Science 2010; 365: 438-446.

http://dx.doi.org/10.1016/j.memsci.2010.09.043

[97] Khodabakhshi AR, Madaeni SS, Hosseini SM. Investigation of electrochemical and morphological properties of S-PVC based heterogeneous cation-exchange membranes modified by sodium dodecyl sulphate. Separation and Purification Technology 2011; 77: 220-229.

\section{http://dx.doi.org/10.1016/j.seppur.2010.12.009}

[98] Khodabakhshi AR, Madaeni SS, Hosseini SM. Preparation and characterization of monovalent ion-selective poly(vinyl chloride)-blend-poly(styrene-co-butadiene) heterogeneous anion-exchange membranes. Polymer International 2011; 60 : 466-474

http://dx.doi.org/10.1002/pi.2970

[99] Hosseini SM, Madaeni SS, Zendehnam A, Moghadassi AR, Khodabakhshi AR, Sanaeepur $H$. Preparation and characterization of PVC based heterogeneous ion exchange membrane coated with Ag nanoparticles by (thermal-plasma) treatment assisted surface modification. Journal of Industrial and Engineering Chemistry 2013; 19: 854-862. http://dx.doi.org/10.1016/j.jiec.2012.10.031

[100] Hosseini SM, Madaeni SS, Heidari AR, Moghadassi AR. Preparation and characterization of polyvinyl chloride/styrene butadiene rubber blend heterogeneous cation exchange 
membrane modified by potassium perchlorate. Desalination 2011; 279: 306-314.

http://dx.doi.org/10.1016/j.desal.2011.06.022

[101] Hosseini SM, Madaeni SS, Heidari AR, Amirimehr A. Preparation and characterization of ion-selective polyvinyl chloride based heterogeneous cation exchange membrane modified by magnetic iron-nickel oxide nanoparticles. Desalination 2012; 284: 191-199. http://dx.doi.org/10.1016/j.desal.2011.08.057

[102] Kariduraganavar MY, Nagarale RK, Kulkarni SS. Electrodialytic transport properties of heterogeneous cationexchange membranes prepared by gelation and solvent evaporation methods. Journal of Applied Polymer Science 2006; 100: 198-207.

http://dx.doi.org/10.1002/app.22808

[103] Ferreira CA, Casanovas J, Rodrigues MA, Muller F, Armelin $\mathrm{E}$, Alemán C. Transport of metallic ions through polyanilinecontaining composite membranes. Journal of Chemical \& Engineering Data 2010; 55: 4801-4807. http://dx.doi.org/10.1021/je1004033

[104] Amado FDR, Rodrigues MAS, Bertuol DA, Bernardes AM, Ferreira JZ, Ferreira CA. The effect of production method on the properties of high impact polystyrene and polyaniline membranes. Journal of Membrane Science 2009; 330: 227232.

http://dx.doi.org/10.1016/j.memsci.2008.12.065

[105] Amado FD, Rodrigues MA, Morisso FD, Bernardes AM, Ferreira JZ, Ferreira CA. High-impact polystyrene/polyaniline membranes for acid solution treatment by electrodialysis: preparation, evaluation, and chemical calculation. Journal of Colloid and Interface Science 2008; 320: 52-61. http://dx.doi.org/10.1016/j.jcis.2007.11.054

[106] Kattan Readi OM, Kuenen HJ, Zwijnenberg HJ, Nijmeijer K. Novel membrane concept for internal $\mathrm{pH}$ control in electrodialysis of amino acids using a segmented bipolar membrane (sBPM) Journal of Membrane Science 2013; 443: 219-226.

http://dx.doi.org/10.1016/i.memsci.2013.04.045

[107] Hao JH, Li L, Yu LX, Jiang WJ. Preparation of Bipolar Membranes (I). Journal of Applied Polymer Science 2001; 80: 1658-1663.

http://dx.doi.org/10.1002/app.1260

[108] Fu R, Xu T, Yang W, Pan Z. Preparation of a mono-sheet bipolar membrane by simultaneous irradiation grafting polymerization of acrylic acid and chloromethylstyrene Journal of Applied Polymer Science 2003; 90: 572-576. http://dx.doi.org/10.1002/app.12776

[109] Li S-D, Wang C-C, Chen C-Y. Preparation and characterization of a novel bipolar membrane by plasmainduced polymerization. Journal of Membrane Science 2008; 318: 429-434.

http://dx.doi.org/10.1016/j.memsci.2008.03.016

[110] Hao JH, Yu L, Chen C, Li L, Jiang W. Preparation of bipolar membranes. II. Journal of Applied Polymer Science 2001; 82: 1733-1738.

http://dx.doi.org/10.1002/app.2014

[111] Xu T, Yang W. Fundamental studies on a novel series of bipolar membranes prepared from poly(2,6-dimethyl-1,4phenylene oxide) (PPO)I. Effect of anion exchange layers on I-V curves of bipolar membranes. Journal of Membrane Science 2004; 238: 123-129.

http://dx.doi.org/10.1016/i.memsci.2004.03.028

[112] Chen G, Xu T, Liu J. Irradiation-induced grafting of polyacrylamide onto the sulphonated poly(2,6-dimethyl-1,4phenylene oxide) (SPPO) films as well as its use as catalytical layer in a bipolar membrane. Journal of Applied Polymer Science 2008; 109: 1447-1453. http://dx.doi.org/10.1002/app.28276

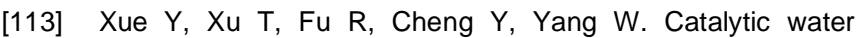
dissociation using hyperbranched aliphatic polyester (Boltorn series) as the interface of a bipolar membrane. Journal of Colloid and Interface Science 2007; 316: 604-611. http://dx.doi.org/10.1016/j.jcis.2007.08.052

[114] Rajesh AM, Kumar M, Shahi VK. Functionalized biopolymer based bipolar membrane with poly ethylene glycol interfacial layer for improved water splitting. Journal of Membrane Science 2011; 372: 249-257.

http://dx.doi.org/10.1016/j.memsci.2011.02.009

[115] Venugopal K, Dharmalingam S. Desalination efficiency of a novel bipolar membrane based on functionalized polysulfone. Desalination 2012; 296: 37-45.

http://dx.doi.org/10.1016/j.desal.2012.04.006

[116] Jeevananda T, Yeon K-H, Moon S-H. Synthesis and characterization of bipolar membrane using pyridine functionalized anion exchange layer. Journal of Membrane Science 2006; 283: 201-208.

http://dx.doi.org/10.1016/j.memsci.2006.06.029

[117] Peng F, Peng S, Huang C, Xu T. Modifying bipolar membranes with palygorskite and $\mathrm{FeCl}_{3}$. Journal of Membrane Science 2008; 322: 122-127. http://dx.doi.org/10.1016/i.memsci.2008.05.027

[118] Chen R-Y, Chen Z, Zheng X, Chen X, Wu S-Y. Preparation and characterization of $\mathrm{mSA} / \mathrm{mCS}$ bipolar membranes modified by CuTsPc and CuTAPc. Journal of Membrane Science 2010; 355: 1-6. http://dx.doi.org/10.1016/j.memsci.2010.01.013

[119] Wang A, Peng S, Wu Y, Huang C, Xu T. A hybrid bipolar membrane. Journal of Membrane Science 2010; 365: 269275. http://dx.doi.org/10.1016/j.memsci.2010.09.016

[120] Xue YH, Fu RQ, Fu YX, Xu TW. Fundamental studies on the intermediate layer of a bipolar membrane V. Effect of silver halide and its dope in gelatin on water dissociation at the interface of a bipolar membrane. Journal of Colloid and Interface Science 2006; 298: 313-320.

http://dx.doi.org/10.1016/j.jcis.2005.11.049

[121] VDV.N. Wilhelm FG, Wessling M, Strathmann H. Bipolar Membrane Preparation. In Handbook on Bipolar Membrane Technology, Kemperman, A. J. B, Ed.; Twente University Press: Enschede 2002; 79-108.

[122] Fu R, Xu T, Wang G, Yang W, Pan Z. PEG-catalytic water splitting in the interface of a bipolar membrane. Journal of Colloid and Interface Science 2003; 263: 386-390. http://dx.doi.org/10.1016/S0021-9797(03)00307-2

[123] Fu RQ, Xue YH, Xu TW, Yang WH. Fundamental studies on the intermediate layer of a bipolar membrane part IV. Effect of polyvinyl alcohol (PVA) on water dissociation at the interface of a bipolar membrane. Journal of Colloid and Interface Science 2005; 285: 281-287.

http://dx.doi.org/10.1016/j.jcis.2004.11.050

[124] Fu RQ, Xu TW, Yang WH, Pan ZX. Fundamental studies on the intermediate layer of a bipolar membrane. Part II. Effect of bovine serum albumin (BSA) on water dissociation at the interface of a bipolar membrane Journal of Colloid and Interface Science 2004; 278: 318-324.

http://dx.doi.org/10.1016/i.jcis.2004.06.006

[125] Fu R. Fundamental studies on the intermediate layer of a bipolar membranePart III. Effect of starburst dendrimer PAMAM on water dissociation at the interface of a bipolar membrane. Journal of Membrane Science 2004; 240: 141147.

http://dx.doi.org/10.1016/j.memsci.2004.05.002

[126] Bauer FJGB, Strathmann H. Development of bipolar membranes. Desalination 1988; 68: 279-292. http://dx.doi.org/10.1016/0011-9164(88)80061-4

[127] Balster J, Srinkantharajah S, Sumbharaju R, Pünt I, Lammertink RGH, Stamatialis DF, Wessling M. Tailoring the interface layer of the bipolar membrane. Journal of Membrane Science 2010; 365: 389-398. http://dx.doi.org/10.1016/j.memsci.2010.09.034 
[128] Kang MS, Choi YJ, Moon SH. Effects of inorganic substances on water splitting in ion-exchange membranes; II. Optimal contents of inorganic substances in preparing bipolar membranes. Journal of Colloid and Interface Science 2004; 273: 533-539.

http://dx.doi.org/10.1016/j.jcis.2004.01.051

[129] Wakamatsu Y, Matsumoto H, Minagawa M, Tanioka A. Effect of ion-exchange nanofiber fabrics on water splitting in bipolar membrane. Journal of Colloid and Interface Science 2006; 300: 442-445.

http://dx.doi.org/10.1016/j.jcis.2006.03.077

[130] Abdu S, Sricharoen K, Wong JE, Muljadi ES, Melin T, Wessling M. Catalytic polyelectrolyte multilayers at the bipolar membrane interface. ACS Applied Materials \& Interfaces 2013; 5: 10445-10455.

http://dx.doi.org/10.1021/am403019y

[131] Huang $\mathrm{CH}, \mathrm{Xu}$ TW, Zhang YP, Xue YH, Chen GW. Application of electrodialysis to the production of organic acids: State-of-the-art and recent developments. Journal of Membrane Science 2007; 288: 1-12.

http://dx.doi.org/10.1016/j.memsci.2006.11.026

[132] Xu TW. Electrodialysis processes with bipolar membranes (EDBM) in environmental protection - a review. Resources Conservation and Recycling 2002; 37: 1-22.

http://dx.doi.org/10.1016/S0921-3449(02)00032-0

[133] Huang $\mathrm{CH}, \mathrm{Xu}$ TW. Electrodialysis with bipolar membranes for sustainable development. Environ Sci Technol 2006; 40: 5233-5243.

http://dx.doi.org/10.1021/es060039p

[134] Xu TW, Huang CH. Electrodialysis-Based Separation Technologies: A Critical Review. AIChE Journal 2008; 54: 3147-3159.

http://dx.doi.org/10.1002/aic.11643

[135] Wang X, Wang Y, Zhang X, Jiang C, Xu T. Noteworthy issues for producing and transforming bioproducts by electrodalysis. Journal of Chemical Technology \& Biotechnology 2014; 89: 1437-1444.

http://dx.doi.org/10.1002/jctb.4415

[136] Logan BE, Elimelech M. Membrane-based processes for sustainable power generation using water Nature 2012; 488: 313-319.

http://dx.doi.org/10.1038/nature11477

[137] Post JW, Hamelers HVM, Buisman CJN. Energy recovery from controlled mixing salt and fresh water with a reverse electrodialysis system. Environ Sci Technol 2008; 42: 57855790.

http://dx.doi.org/10.1021/es8004317

[138] Luo X, Cao XX, Mo YH, Xiao K, Zhang XY, Liang P, Huang $X$. Power generation by coupling reverse electrodialysis and ammonium bicarbonate: Implication for recovery of waste heat Electrochemistry Communications 2012; 19: 25-28. http://dx.doi.org/10.1016/j.elecom.2012.03.004

[139] Akyeva SC, Berkelieva LK, Evzhanov KN. Wastewater treatment of phosphate ions by the electrodialysis method. Journal of Water Chemistry and Technology 2008; 30: 246250.

http://dx.doi.org/10.3103/S1063455X08040085

[140] Young CL, Ingall ED. Marine Dissolved Organic Phosphorus Composition: Insights from Samples Recovered Using Combined Electrodialysis/Reverse Osmosis. Aquat Geochem 2010; 16: 563-574.

http://dx.doi.org/10.1007/s10498-009-9087-y

[141] Keramati N, Moheb A, Ehsani MR. Effect of operating parameters on $\mathrm{NaOH}$ recovery from waste stream of Merox tower using membrane systems: Electrodialysis and electrodeionization processes. Desalination 2010; 259: 97102.

http://dx.doi.org/10.1016/j.desal.2010.04.027
[142] Onuki K, Hwane GJ, Shimizu S. Electrodialysis of hydriodic acid in the presence of iodine. Journal of Membrane Science 2000; 175: 171-179. http://dx.doi.org/10.1016/S0376-7388(00)00415-4

[143] Sow PK, Shukla A. Electro-electrodialysis for concentration of hydroiodic acid Int J Hydrogen Energ 2012; 37: 39313937.

http://dx.doi.org/10.1016/j.ijhydene.2011.04.157

[144] Rohman FS, Aziz N. Optimization of batch electrodialysis for hydrochloric acid recovery using orthogonal collocation method. Desalination 2011; 275: 37-49.

http://dx.doi.org/10.1016/j.desal.2011.02.025

[145] Rohman FS, Othman MR, Aziz N. Modeling of batch electrodialysis for hydrochloric acid recovery. Chemical Engineering Journal 2010; 162: 466-479. http://dx.doi.org/10.1016/j.cej.2010.05.030

[146] Amara M, Kerdjoudj H. Modified membranes applied to metallic ion separation and mineral acid concentration by electrodialysis. Separation and Purification Technology 2002; 29: 79-87. http://dx.doi.org/10.1016/S1383-5866(02)00084-9

[147] Paquay E, Clarinval AM, Delvaux A, Degrez M, Hurwitz HD. Applications of electrodialysis for acid pickling wastewater treatment. Chemical Engineering Journal 2000; 79: 197-201. http://dx.doi.org/10.1016/S1385-8947(00)00208-4

[148] Boucher M, Turcotte N, Guillemette V, Lantagne G, Chapotot A, Pourcelly G, Sandeaux R, Gavach C. Recovery of spent acid by electrodialysis in the zinc hydrometallurgy industry: Performance study of different cation-exchange membranes. Hydrometallurgy 1997; 45: 137-160. http://dx.doi.org/10.1016/S0304-386X(96)00069-2

[149] Lan SJ, Wen XM, Zhu ZH, Shao F, Zhu CL. Recycling of spent nitric acid solution from electrodialysis by diffusion dialysis. Desalination 2011; 278: 227-230. http://dx.doi.org/10.1016/j.desal.2011.05.031

[150] Moresi M, Sappino F. Effect of some operating variables on citrate recovery from model solutions by electrodialysis. Biotechnol Bioeng 1998; 59: 344-350. http://dx.doi.org/10.1002/(SICl)10970290(19980805)59:3<344::AID-BIT10>3.0.CO;2-E

[151] Xu TW, Yang WH. Effect of cell configurations on the performance of citric acid production by a bipolar membrane electrodialysis. Journal of Membrane Science 2002; 203: 145-153. http://dx.doi.org/10.1016/S0376-7388(01)00795-5

[152] Xu TW, Yang WH. Citric acid production by electrodialysis with bipolar membranes. Chemical Engineering and Processing 2002; 41: 519-524. http://dx.doi.org/10.1016/S0255-2701(01)00175-1

[153] Pinacci P, Radaelli M. Recovery of citric acid from fermentation broths by electrodialysis with bipolar membranes Desalination 2002; 148: 177-179. http://dx.doi.org/10.1016/S0011-9164(02)00674-4

[154] Novalic S, Kulbe KD. Separation and concentration of citric acid by means of electrodialytic bipolar membrane technology. Food Technol Biotech 1998; 36: 193-195.

[155] Ling LP, Leow HF, Sarmidi MR. Citric acid concentration by electrodialysis: ion and water transport modelling. Journal of Membrane Science 2002; 199: 59-67. http://dx.doi.org/10.1016/S0376-7388(01)00678-0

[156] Luo GS, Shan XY, Qi X, Lu YC. Two-phase electroelectrodialysis for recovery and concentration of citric acid. Separation and Purification Technology 2004; 38: 265-271. http://dx.doi.org/10.1016/i.seppur.2003.12.002

[157] Bai L, Wang XL, Nie Y, Dong HF, Zhang XP, Zhang SJ. Study on the recovery of ionic liquids from dilute effluent by electrodialysis method and the fouling of cation-exchange membrane. Sci China Chem 2013; 56: 1811-1816. http://dx.doi.org/10.1007/s11426-013-5016-4 
[158] I.A.f.R.o. Cancer, IARC monographs on the evaluation of carcinogenic risks to humans, volume 49-Chromium, nickel and welding, Lyon, IARC 1990; p. 677.

[159] Gayathri R, Kumar PS. Recovery and reuse of hexavalent chromium from aqueous solutions by a hybrid technique of electrodialysis and ion exchange. Brazilian Journal of Chemical Engineering 2010; 27: 71-78.

http://dx.doi.org/10.1590/S0104-66322010000100006

[160] Nataraj SK, Hosamani KM, Aminabhavi TM. Potential application of an electrodialysis pilot plant containing ionexchange membranes in chromium removal. Desalination 2007; 217: 181-190.

http://dx.doi.org/10.1016/j.desal.2007.02.012

[161] Peng CS, Meng H, Song SX, Lu S, Lopez-Valdivieso A. Elimination of $\mathrm{Cr}(\mathrm{VI})$ from electroplating wastewater by electrodialysis following chemical precipitation. Separation Science and Technology 2004; 39: 1501-1517. http://dx.doi.org/10.1081/SS-120030788

[162] Benvenuti T, Krapf RS, Rodrigues MAS, Bernardes AM, Zoppas-Ferreira J. Recovery of nickel and water from nickel electroplating wastewater by electrodialysis. Separation and Purification Technology 2014; 129: 106-112. http://dx.doi.org/10.1016/j.seppur.2014.04.002

[163] Li CL, Zhao HX, Tsuru T, Zhou D, Matsumura M. Recovery of spent electroless nickel plating bath by electrodialysis. Journal of Membrane Science 1999; 157: 241-249. http://dx.doi.org/10.1016/S0376-7388(98)00381-0

[164] Spoor PB, Grabovska L, Koene L, Janssen LJJ, ter Veen WR. Pilot scale deionisation of a galvanic nickel solution using a hybrid ion-exchange/electrodialysis system. Chemical Engineering Journal 2002; 89: 193-202. http://dx.doi.org/10.1016/S1385-8947(02)00009-8

[165] Dermentzis K. Removal of nickel from electroplating rinse waters using electrostatic shielding electrodialysis/ electrodeionization. Journal of Hazardous Materials 2010; 173: 647-652.

http://dx.doi.org/10.1016/j.jhazmat.2009.08.133

[166] De Ketelaere RF, Linden JV. Selective recovery of nickel from industrial effluents by supported liquid membranes (SLM) and modified electrodialysis (MED) 1999.

[167] Bolger PT, Szlag DC. Investigation into the rejuvenation of spend electroless nickel baths by electrodialysis. Environ Sci Technol 2002; 36: 2273-2278.

http://dx.doi.org/10.1021/es015610t

[168] Hoshino T. Development of high-efficiency lithium recovery from seawater by electrodialysis using ionic liquid. Abstracts of Papers of the American Chemical Society 2013; 245.

[169] Peng CS, Liu YY, Bi JJ, Xu HZ, Ahmed AS. Recovery of copper and water from copper-electroplating wastewater by the combination process of electrolysis and electrodialysis. Journal of Hazardous Materials 2011; 189: 814-820. http://dx.doi.org/10.1016/j.jhazmat.2011.03.034

[170] Caprarescu S, Purcar V, Vaireanu D-I. Separation of Copper Ions from Synthetically Prepared Electroplating Wastewater at Different Operating Conditions using Electrodialysis. Separation Science and Technology 2012; 47: 2273-2280.

[171] Nunez P, Hansen HK. Electroleaching of Copper Waste with Recovery of Copper by Electrodialysis, in: N. Pirrone (Ed.) Proceedings of the 16th International Conference on Heavy Metals in the Environment 2013.

[172] Mahmoud A, Hoadley AFA. An evaluation of a hybrid ion exchange electrodialysis process in the recovery of heavy metals from simulated dilute industrial wastewater. Water Res 2012; 46: 3364-3376.

http://dx.doi.org/10.1016/j.watres.2012.03.039

[173] Chakrabarty T, Shah B, Srivastava N, Shahi VK, Chudasama U. Zirconium tri-ethylene tetra-amine ligand-chelator complex based cross-linked membrane for selective recovery of $\mathrm{Cu} 2+$ by electrodialysis. Journal of Membrane Science 2013; 428: 462-469.

http://dx.doi.org/10.1016/j.memsci.2012.10.056

[174] Chen J, Jiang YF. A Feasibility Study of Wastewater Containing $\mathrm{Pb}$ (II) Recovery Using Electrodialysis Reversal, in: H. Li, Q.J. Xu, D. Zhang (Eds.) Progress in Environmental Science and Engineering 2012; pp. 2007-2014.

[175] Abou-Shady A, Peng CS, Bi JJ, Xu HZ, O JA. Recovery of $\mathrm{Pb}$ (II) and removal of NO3- from aqueous solutions using integrated electrodialysis, electrolysis, and adsorption process. Desalination 2012; 286: 304-315.

http://dx.doi.org/10.1016/j.desal.2011.11.041

[176] Cifuentes L, Garcia I, Arriagada P, Casas JM. The use of electrodialysis for metal separation and water recovery from CuSO4-H2SO4-Fe solutions. Separation and Purification Technology 2009; 68: 105-108. http://dx.doi.org/10.1016/j.seppur.2009.04.017

[177] Amado FDR, Rodrigues LF, Rodrigues MAS, Bernardes AM, Ferreira JZ, Ferreira CA. Development of polyurethane/polyaniline membranes for zinc recovery through electrodialysis. Desalination 2005; 186: 199-206. http://dx.doi.org/10.1016/j.desal.2005.05.019

[178] Sadyrbaeva TZ. Recovery of manganese(II) by electrodialysis with liquid membranes based on di(2ethylhexyl)phosphoric acid. Russian Journal of Applied Chemistry 2009; 82: 1008-1013.

http://dx.doi.org/10.1134/S1070427209060147

[179] Meguro Y, Kato A, Watanabe Y, Takahashi K. Asme, Separation and recovery of sodium nitrate from low-level radioactive liquid waste by electrodialysis, Proceedings of the 13th International Conference on Environmental Remediation and Radioactive Waste Management 2010; Vol. 1.

[180] Majewska-Nowak K. Recovery of Dyes and Mineral Salts from Process Waters by Batch Electrodialysis with Monoanion Selective Ion-exchange Membranes. Ochrona Srodowiska 2012; 34: 35-42.

[181] Strathmann H. Ion-exchange membrane separation processes, Elsevier 2004. 